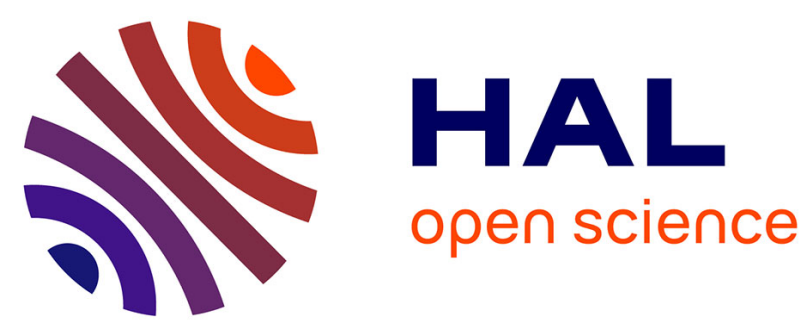

\title{
Future climatic and hydrologic changes estimated by bias-adjusted regional climate model outputs of the Cordex-Africa project: case of the Tafna basin (North-Western Africa)
}

Amina Mami, Mélanie Raimonet, Djilali Yebdri, Sabine Sauvage, Amin Zettam, J.M. Sánchez-Pérez

\section{To cite this version:}

Amina Mami, Mélanie Raimonet, Djilali Yebdri, Sabine Sauvage, Amin Zettam, et al.. Future climatic and hydrologic changes estimated by bias-adjusted regional climate model outputs of the Cordex-Africa project: case of the Tafna basin (North-Western Africa). International Journal of Global Warming, 2021, 23 (1), pp.58-90. 10.1504/IJGW.2021.112489 . hal-03430756

\author{
HAL Id: hal-03430756 \\ https://hal.science/hal-03430756
}

Submitted on 16 Nov 2021

HAL is a multi-disciplinary open access archive for the deposit and dissemination of scientific research documents, whether they are published or not. The documents may come from teaching and research institutions in France or abroad, or from public or private research centers.
L'archive ouverte pluridisciplinaire HAL, est destinée au dépôt et à la diffusion de documents scientifiques de niveau recherche, publiés ou non, émanant des établissements d'enseignement et de recherche français ou étrangers, des laboratoires publics ou privés. 


\section{Future climatic and hydrologic changes estimated by bias-adjusted regional climate model outputs of the Cordex-Africa project: case of the Tafna basin (North-Western Africa)}

\section{Amina Mami*}

Laboratoire de recherche de gestion et traitement des eaux (LGTE),

Faculté d'Architecture et de Génie Civil,

Université des Sciences et de la Technologie d'Oran,

Mohamed Boudiaf, 31000 Oran, Algeria

Email: amina.mami@univ-usto.dz

and

Laboratoire Ecologie Fonctionnelle et Environnement,

INP-Toulouse, 31326 Toulouse, France

Email: mami.amina89@yahoo.fr

*Corresponding author

\section{Mélanie Raimonet}

Laboratoire Ecologie Fonctionnelle et Environnement,

CNRS, INP-Toulouse, UPS,

Université de Toulouse,

31326 Toulouse, France

Email: melanie.raimonet@gmail.com

\section{Djilali Yebdri}

Laboratoire de recherche de gestion et traitement des eaux (LGTE),

Faculté d'Architecture et de Génie Civil,

Université des Sciences et de la Technologie d'Oran,

Mohamed Boudiaf, 31000 Oran, Algeria

Email: dyebdri@yahoo.fr

\section{Sabine Sauvage}

Laboratoire Ecologie Fonctionnelle et Environnement,

CNRS, INP-Toulouse, UPS,

Université de Toulouse,

31326 Toulouse, France

Email: sabine.sauvage@univ-tlse3.fr 


\title{
Amin Zettam
}

Laboratory of Ecology and Natural

Ecosystems Management (LECGEN),

Faculty of Natural and Life Sciences and

Earth and Universe Sciences (SNVSTU),

Tlemcen University, 13000 Tlemcen, Algeria

Email: zettam.amine@gmail.com

\section{José Miguel Sanchez Perez}

Laboratoire Ecologie Fonctionnelle et Environnement,

CNRS, INP-Toulouse, UPS,

Université de Toulouse,

31326 Toulouse, France

Email: jose-miguel.sanchez-perez@univ-tlse3.fr

\begin{abstract}
This study investigates climatic and hydrologic changes of the Tafna basin, by using ten outputs of precipitation and temperature from RCMs of the Cordex-Africa project. Different methods of bias-correction (LS, LOCI, DM and VS) are compared to correct the bias of precipitation and temperature datasets to observations. The suitable method, DM, reduces the bias to $1.27 \mathrm{~mm}$ for precipitation and 0.06 and $0.7^{\circ} \mathrm{C}$ for minimum/maximum temperature, respectively. The bias-corrected precipitation and temperature datasets are introduced into the SWAT model, calibrated and validated on the Tafna basin with good Nash criteria (NSEoutlet $=0.83$ ). The discharge is over or under-estimated without bias-correction of RCM outputs, which highlights the necessity of applying bias-correction before using RCM outputs from Cordex-Africa for hydrological applications. The results show that the precipitation and discharge decreases, and temperature increases are more important with RCP 8.5 than with RCP 4.5 , especially in the last decades of the 21 st century.
\end{abstract}

Keywords: Tafna basin; precipitation; Cordex-Africa; bias-correction; climate change; discharge.

Reference to this paper should be made as follows: Mami, A., Raimonet, M., Yebdri, D., Sauvage, S., Zettam, A. and Sanchez Perez, J.M. (2021) 'Future climatic and hydrologic changes estimated by bias-adjusted regional climate model outputs of the Cordex-Africa project: case of the Tafna basin (North-Western Africa)', Int. J. Global Warming, Vol. 23, No. 1, pp.58-90.

Biographical notes: Amina Mami is a PhD student at Université des Sciences et de la Technologie d'Oran 'Mohamed BOUDIAF', and Institut National Polytechnique de Toulouse. She received her Master's degree from Université des Sciences et de la Technologie d'Oran 'Mohamed BOUDIAF'. Her research interests include water resource management, and impact of climate change on water resources in the Mediterranean region. 
Mélanie Raimonet holds a $\mathrm{PhD}$ in Marine Biology. She currently works at EcoLab - Laboratoire d'écologie fonctionnelle. She does research in hydro-biogeochemistry and ecology. Her current project is 'AGUAMOD'.

Djilali Yebdri is a Professor at Université des Sciences et de la Technologie d'Oran 'Mohamed BOUDIAF', He holds a PhD in Hydraulic (2006) from Université des Sciences et de la Technologie d'Oran 'Mohamed BOUDIAF'. His research is focused on the water resource management and development of reservoir management in the Nord-Western Africa.

Sabine Sauvage is a Research Engineer class assigned to Laboratory (CNRS Université Paul Sabatier - INP Toulouse). He obtained his PhD obtained on November 1999 from INP Toulouse, France. He holds a Habilitation for Managing Research (2010) in University of Toulouse, France. His research has been focused on the development of models that describe the bio-physical interactions between the flows, biology and chemistry of the biogenic elements and contaminants in rivers by integrating interface zones and buffer zones between the surface water and the river beds from the scale of the processes to the scale of the watershed.

Amin Zettam is an Algerian Scientist assigned to Laboratory of Ecology and Natural Ecosystems Management (LECGEN), Faculty of Natural and Life Sciences and Earth and Universe Sciences (SNVSTU), Tlemcen University Algeria. PhD (2018) in Hydrology, hydrochemistry, soil, Environnement from the NATIONAL POLYTECHNIC INSTITUTE OF TOULOUSE (France); $\mathrm{PhD}$ (2018) in Aquatic Ecosystem: Biodiversity, Functioning and Anthropisation from Tlemcen (Algeria). He studies pollutant transport in hydrologic systems, using modeling.

José Miguel Sanchez Perez is a Research Director assigned to Laboratory (CNRS - Université Paul Sabatier - INP Toulouse). He earned his PhD (1992) in Hydrogeochemistry from the University of Strasbourg (France), MS (1985) in Geoloy from University of the Basque Country (Spain). His is focus in biogeochemical functioning of buffers zones. He studies pollutant transport in hydrosystems, using extensive field data and modelling. He specialises in the functioning of wetlands, riparian zones, and groundwater systems, with particular interests in the modelling of catchment-scale pollutant transport, to predict how ecosystem functions will change under various climate change scenarios.

\section{Introduction}

The Mediterranean region is considered particularly vulnerable to climate variability and change because of its sensitivity to changes in the water cycle (Rosenzweig et al., 2007; UNEP/MAP-Plan Bleu, 2009). In the Mediterranean region, several studies mentioned decreases in rainfall ranging between $-10 \%$ and $-40 \%$ in the North-Eastern Morocco and North-Western Algeria using the ECHAM4/OPYC3 model, and between $-10 \%$ and $-20 \%$ in Greece (Zanis et al., 2009) and in the Gàllego basin in Spain (Majone et al., 2012) using the Prudence project. Ruti et al. (2016) mention that areas surrounding the Mediterranean basin have quite a unique character with similar climatic conditions and 
morphologic characteristics. Currently, the Southern and Eastern rims are experiencing high to severe water stress. By the 2050 horizon, this stress could increase over the whole Mediterranean basin, notably because of a 30\%-50\% decline in freshwater resources as a result of climate change (Milano et al., 2013).

At the start of the 1970s, the impacts of climate change began to appear in Northern Africa, with an increase in temperature and a decrease in rainfall (Knippertz et al., 2003; Taibi et al., 2017). The North-Western region of Algeria is characterised by a rainfall decrease of $-25 \%$ in the 1970 s evaluated by studies done throughout 1950 to 2004 (Taibi et al., 2017; Meddi et al., 2010), and an increase of temperature +1 to $+1.25^{\circ} \mathrm{C}$ since 1901 to 2010 (Zeroual et al., 2018; IPCC Working Group I et al., 2013). A warming trend is even expected to continue at a rate of $+0.2^{\circ} \mathrm{C}$ per decade for the next 20 years (Bernstein et al., 2007). These variations associated with climate change are expected to increase the vulnerability of semi-arid regions regarding water scarcity.

Impacts of climate change on water resources can be exacerbated in regions already presenting low water resources levels and frequent droughts, and subject to imbalances between water demand and available water resources, like in Northern Africa (Estrela et al., 2012). In Algeria, the Tafna basin belongs to these vulnerable regions, especially concerning drinking water supply. Some studies already mention that the discharge decreases until $-60 \%$ in the decade of 1970 evaluated by studies done from 1930 to 1998 (Meddi and Hubert, 2003; Meddi et al., 2009).

In order to evaluate hydrological impacts of climate change to support water management decisions in local drainage basins, one possibility is the application of regional climate models (RCMs) to force a hydrological model to study future projections under different scenarios. The use of raw RCM outputs, in some regions, may decrease the efficiency of the hydrological trend evaluation, and cannot be used directly (Senent-Aparicio et al., 2017). Different studies recommend the use of bias-correction of RCM outputs (Lenderink et al., 2007; Wilby et al., 2000; Brouziyne et al., 2018) to minimise errors between observed and simulated climate variables, when the aim is to investigate hydrological impacts (Muerth et al., 2013).

Some studies controvert the application of bias correction on RCMs or global climate models (GCMs) to future periods based on bias determined for the past period. Some correction methods are criticised to reduce the advantage of climate model projections if the bias is due to an accidental calculation error, then the parameter corrected can change the tendency (Muerth et al., 2013; Ehret et al., 2012; Hagemann et al., 2004; Teutschbein and Seibert, 2013). However, as the absence of bias-correction for future projections could lead to errors for hydrological impact studies (Muerth et al., 2013) and as the precipitation bias is particularly high in the Mediterranean region (Kotlarski et al., 2014), bias-correction could be expected in this region.

To evaluate the impact of the use of bias-corrected RCM outputs on hydrology in the future, the regional downscaling of GCM to RCM is developed by different institutes and homogenised through the Cordex project (ESGF-LIU, n.d.). This project is sponsored by the World Climate Research Program (WCRP) (CORDEX, n.d.) to develop an improved regional climate change projections for all land regions worldwide. Africa-Cordex is one of the fourteen domains of the international Cordex initiative and covers the African continent. However, the bias-correction of RCM outputs studies using Cordex-Africa are concentrated in Central-Western and Southern Africa, e.g., Hernández-Díaz et al. (2013) and Mascaro et al. (2015), but only a few on the Northern Africa, e.g., Ruti et al. (2016), Zeroual et al. (2018) and Brouziyne et al. (2018). 
The basic principle is that biases between simulated climate time series and observations are quantified and then used to correct both control and scenario runs (Teutschbein and Seibert, 2010). Some methods of bias correction used by impact modellers are linear scaling (LS), local intensity scaling (LOCI), distribution mapping (DM), empirical quantile mapping, delta change and quantile-quantile corrections (Senent-Aparicio et al., 2017; Lenderink et al., 2007; Teutschbein and Seibert, 2013, 2012; Amengual et al., 2012; Ahmed et al., 2015; Chen et al., 2013; Fang et al., 2015; Schmidli et al., 2006; Luo et al., 2018; Leander and Buishand, 2007; Shin et al., 2018). Kotlarski et al. (2014) mention that precipitation biases are generally in the range $-40 \%$ and $+80 \%$ in the Mediterranean basin under the Cordex project, and regionally averaged temperature biases are mostly less than $1.5^{\circ} \mathrm{C}$, suggesting that bias correction would be needed before hydrological applications.

The outputs from hydrological prediction models can have a direct impact on decisions with regard to water resources management (Zettam et al., 2017). Among these models, the soil and water assessment tool (SWAT) model (Arnold et al., 2012) is one of the most widely used model in the world (Senent-Aparicio et al., 2017; Zettam et al., 2017; Grusson et al., 2017; Brouziyne et al., 2017; Adnan et al., 2019; Bouraoui et al., 2005; Srinivasan et al., 2010; Osei et al., 2019; Blanco-Gómez et al., 2019) to simulate watershed hydrology. The SWAT model has already been applied on the Tafna basin with the 1999 version for water resource management (Hagemann et al., 2004) (an old version without GIS interface), and with the 2012 version for modelling of sediment transport (Meddi and Hubert, 2003). This study goes further and investigates climatic and hydrologic changes on the Tafna basin until the end of the 21 st century.

The aim of this study is to evaluate climatic and hydrologic changes in the Tafna basin using bias-corrected RCM outputs of the Cordex-Africa project. First, the SWAT hydrological model is applied to the Tafna basin for the reference period (1981-2010). Then, we test and evaluate three bias-correction methods on precipitation and temperature outputs from ten RCMs of the Cordex-Africa project for the reference period. Finally, we assess both the impact of precipitation and temperature bias-correction on hydrological outputs and the future evolution of monthly climatic and hydrologic variables between 2000 and 2100 under two emission scenarios RCP 4.5 and RCP 8.5.

\section{Materials and methods}

\subsection{Study area and observed data}

The Tafna basin is located in the North-West of Algeria. It is a transboundary watershed, with about $30 \%$ of its surface area in Morocco (Yebdri et al., 2007). The Tafna basin is one of the biggest five basins of North-Western Algeria according to the classification of the Agence Nationale des Ressources Hydriques (ANRH: National Water Resources Agency, 1981). The Tafna catchment covers approximately $7,245 \mathrm{~km}^{2}$ and discharges into the Mediterranean Sea near Beni-saf City (Figure 1). 
Figure 1 Location of the Tafna catchment (see online version for colours)

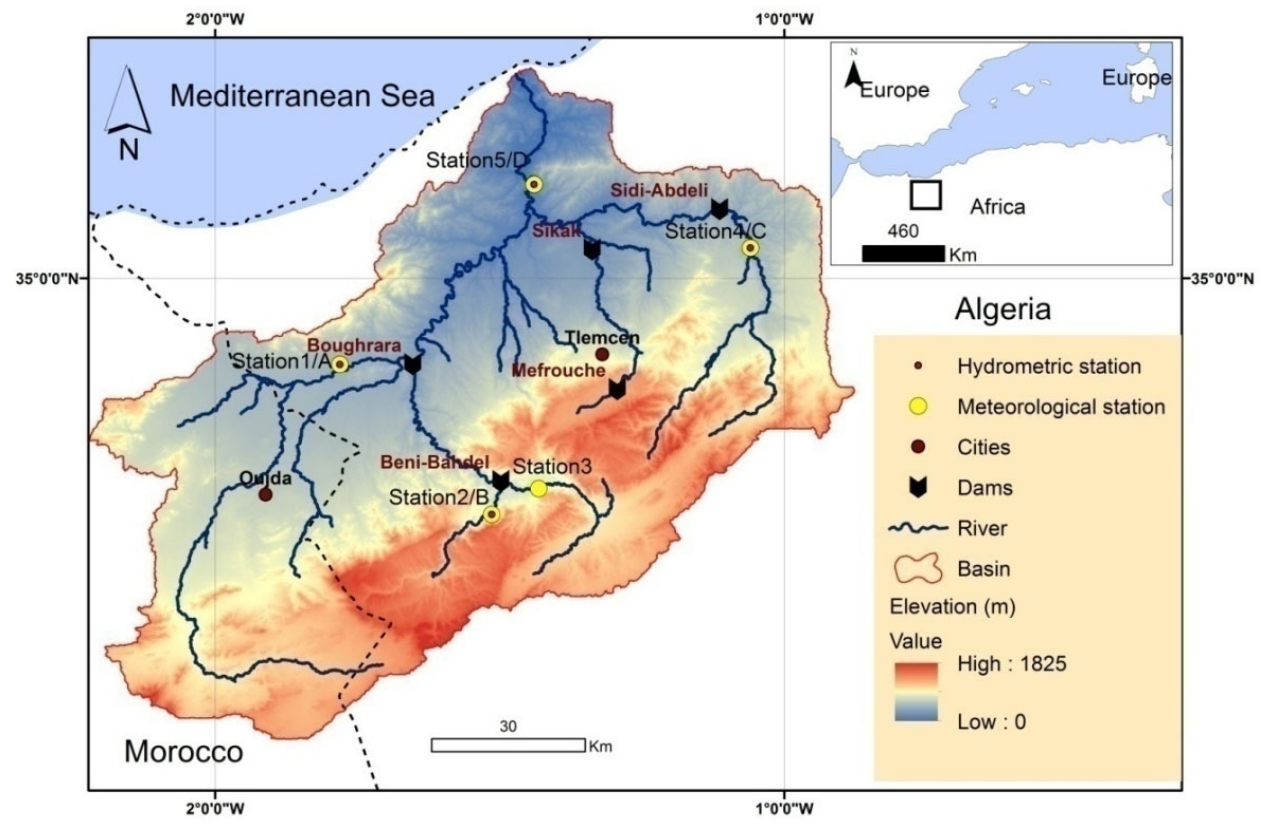

Note: Each station is associated with a number for meteorological station and/or a letter for hydrometric station.

\subsection{Meteorological and hydrological datasets}

Meteorological and hydrological datasets are used in this study (Table 1). The stations 1 to 5 record meteorological parameters (precipitation and temperature) collected by the National Agency of the Meteorology of Algeria, and the stations A to D record the hydrometric parameter (river discharge) measured by ANRH (Figure 1).

Table 1 Observations parameters category's

\begin{tabular}{lccc}
\hline Stations & Category of stations & Parameters studied & Period studied \\
\hline From 1 to 5 & Meteorological & $\begin{array}{c}\text { Precipitations, minimum/maximum } \\
\text { temperature }\end{array}$ & $1981-2011$ \\
& & Discharge & $1981-2011$ \\
\hline
\end{tabular}

Daily meteorological datasets include precipitation and maximum/minimum temperature for five stations for the period 1981-2000 (Figure 1). The climate of the Tafna basin is semi-arid (Yebdri et al., 2007), and characterised by wet winters (from November to March) and hot and dry summers between June and October (Zettam et al., 2017). Annual mean temperature varies between $11^{\circ} \mathrm{C}$ in winter (December to February) and $28^{\circ} \mathrm{C}$ in summer (June to August), and annual precipitations range from 220 to 
$673 \mathrm{~mm} / \mathrm{yr}$ during 1981-2000 (ANRH, 1981). It is an intermediate zone between the Mediterranean Sea and the Sahara Desert. There are five dams in the Tafna basin: Beni Bahdel (built in 1952, with capacity of $63 \mathrm{~mm}^{3}$ ), Mefrouche $\left(1963,15 \mathrm{~mm}^{3}\right)$, Sidi Abdely $\left(1988,110 \mathrm{~mm}^{3}\right)$, Boughrara $\left(1998,177 \mathrm{~mm}^{3}\right)$ and Sikak $\left(2005,27 \mathrm{~mm}^{3}\right)$.

In terms of periodic average and for the period studied 1981-2000, monthly precipitations, and minimum/maximum temperature in Tafna basin are specified in Figure 2. Generally, in summer (from June to September) the precipitations are almost negligible, not exceeding $10 \mathrm{~mm}$, and in winter (from November to March) vary between 20 and $60 \mathrm{~mm}$. While the monthly maximum temperature is considerably pronounced in summer (July and August) and reach $33^{\circ} \mathrm{C}$, and the minimum temperature in winter (from November to March) can decrease on average until $2{ }^{\circ} \mathrm{C}$. The discharge recorded during the studied period (1981-2000) ranges on average between 0 and $10 \mathrm{~m}^{3} . \mathrm{s}^{-1}$.

Figure 2 Observed mean monthly discharge, mean monthly precipitation and mean monthly maximum/minimum temperature of the period 1981-2000 (see online version for colours)
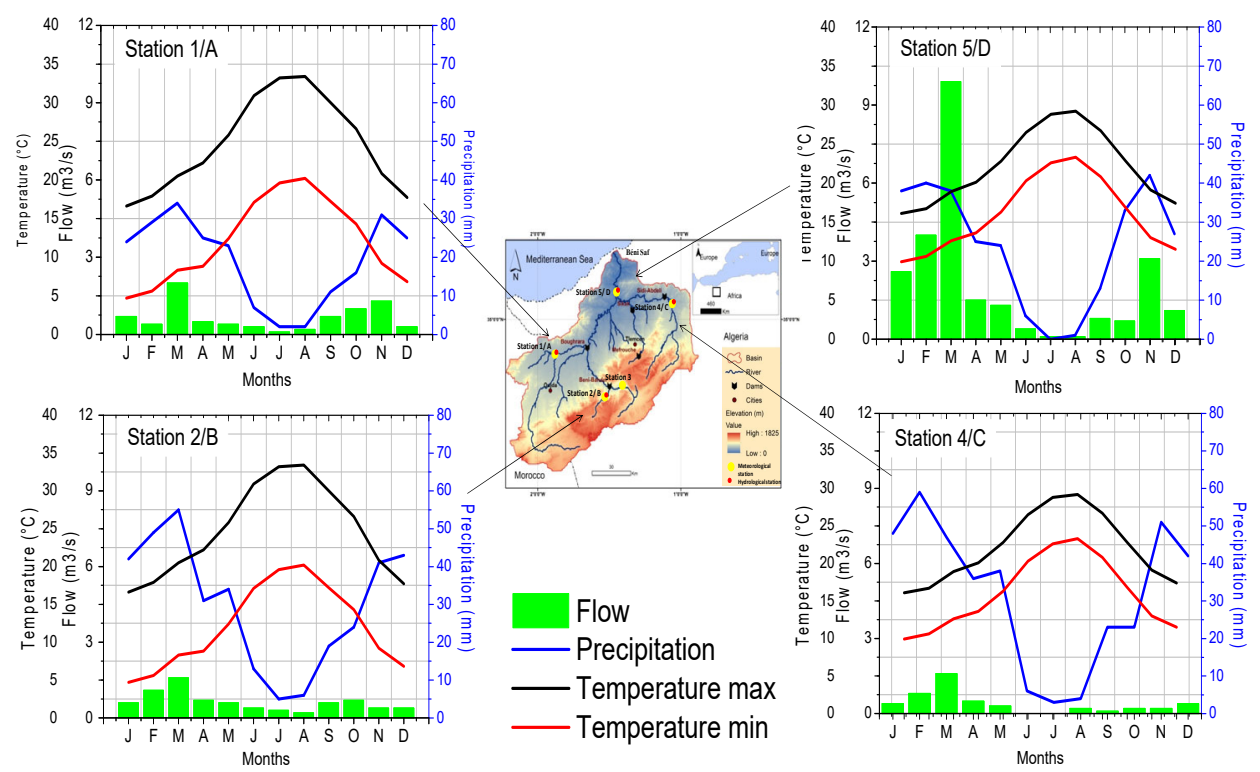

\subsection{RCM outputs}

Ten RCM outputs from the Cordex-Africa project (CORDEX Data Search, n.d.) are used in this work (Table 2). Two RCMs are used and forced with eight different global climate models (GCM): the regional climate model CCLM4-8-17 is forced by EC-EARTH and CNRM-CM5; and RCA4 is forced by EC-EARTH, CNRM-CM5, IPSL-CM5A-MR, CCCma-CanESM2, MIROC5, MPI-ESM-LR, NCC-NorESM1 and NOAA/GFDL-ESM2M. The grid spacing of RCMs used in this study is 0.44 degrees (50 km of resolution). The reference period is adjusted to the period of available observations (1981-2000). 
Table 2 List of RCM outputs used in this study

\begin{tabular}{lcc}
\hline Regional climate model $($ RCM $)$ & Institute & Global climate model $($ GCM $)$ \\
\hline CCLM4-8-17 & Climate Limited-Area & EC-EARTH \\
& Modeling Community & CNRM-CM5 \\
(CLMcom) & EC-EARTH \\
RCA4 & Swedish Meteorological & CNRM-CM5 \\
& and Hydrological & Institute (SHMI) \\
& & IPSL-CM5A-MR \\
& & CCCma-CanESM2 \\
& MIROC5 \\
& MPI-ESM-LR \\
& NCC-NorESM1 \\
\end{tabular}

Note: The domain used is Africa with $50 \mathrm{~km}$ of resolution).

Source: GCM and RCM models can be found on the CORDEX website (CORDEX Data Search, n.d.)

\subsection{Bias correction methods}

Several bias correction methods are used to correct precipitation and temperature datasets (Table 3). Three bias correction methods are compared for precipitation (LS, DM and LOCI) and three methods for temperature [LS, DM and variance scaling (VS)]. The raw RCM outputs are obtained from the Cordex-Africa project (CORDEX Data Search, n.d.) in the form of NetCDF files. The extraction and bias-correction of the RCMs outputs (precipitation and minimum/maximum temperature) are performed with the CMhyd(C) software (Rathjens et al., 2016), which has been successfully used in various studies in Spain (Senent-Aparicio et al., 2017), Morocco (Brouziyne et al., 2018) and Maryland (Xiang et al., 2018).

A dynamical downscaling has already been applied on GCMs to provide the RCMs of different domains [Africa (AFR), Europe (EURO), Middle East North Africa (MENA), etc.] (CORDEX, n.d.). However, the bias-correction consists to proceed with an additional and statistical downscaling on the studied region. The statistical downscaling or a bias-correction consists in reducing the bias between the RCMs outputs and observations. The procedure of bias-correction of RCMs outputs is carried out according to the equations shown in Table 3, by the linear methods (LS, LOCI and VS) and nonlinear method (DM). More information about these methods is found in Teutschbein and Seibert (2012) and Fang et al. (2015). 
Table 3 Description of bias-correction methods used in this study

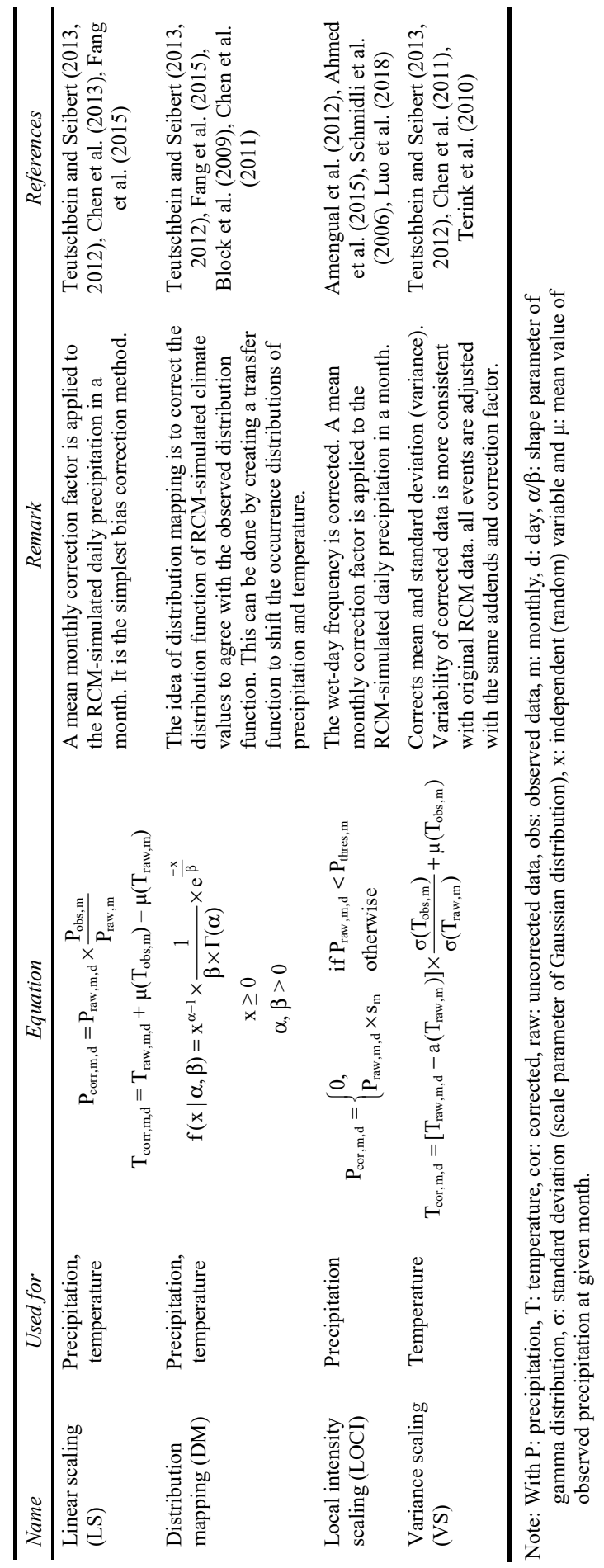




\subsection{Hydrological modelling}

The SWAT model is designed for application in catchments ranging from a few hundred to several thousand square kilometres (Zettam et al., 2017), which is the case of the Tafna basin covering a surface of $7,245 \mathrm{~km}^{2}$. The application is divided into three steps:

1 the bias-correction of RCMs precipitation and temperature by different methods (see Section 2.4)

2 the creation, calibration, and validation of the SWAT model for the Tafna basin

3 the run of the model forced with a set of bias-corrected RCMs outputs to study the future climatic and hydrologic change (2000-2100).

Figure 3 Maps, (a) $30 \mathrm{~m}$ DEM (b) soils (c) land slope classes (d) sub-basins delineated by SWAT (e) mains land uses (see online version for colours)

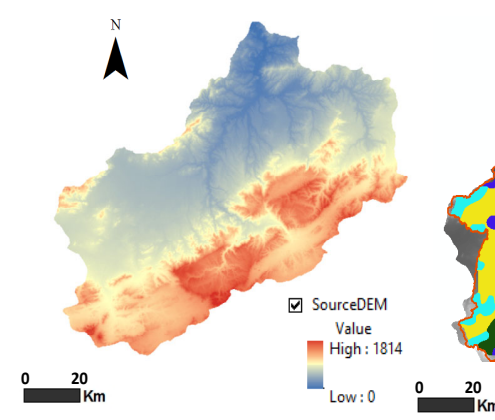

(a)

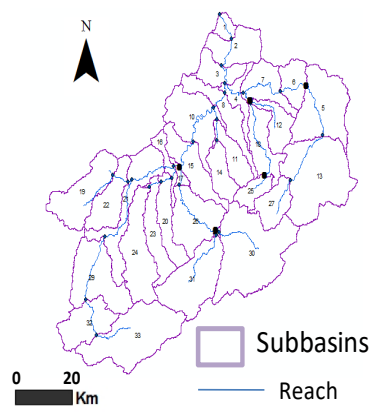

(d)

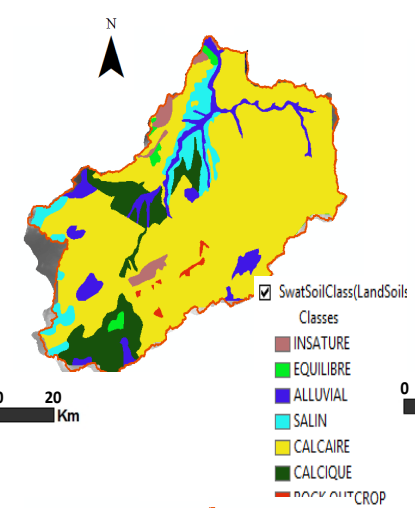

(b)

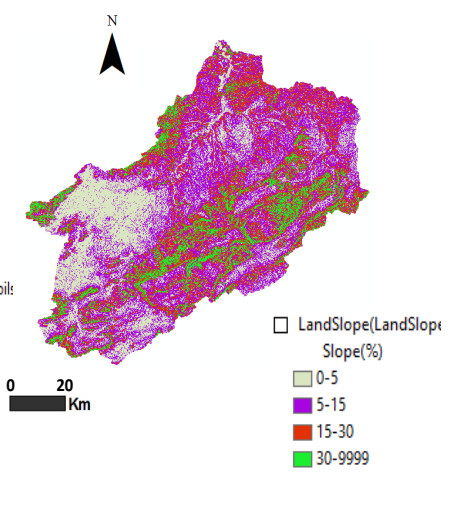

(c)

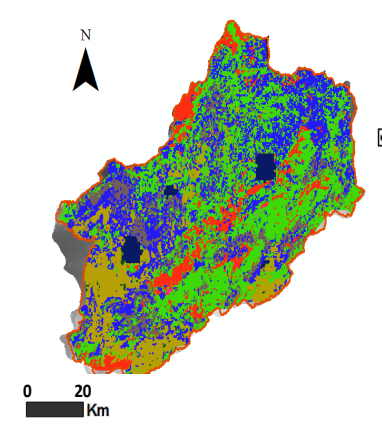

(e)

The SWAT model is created with the 2012 version with an ArcGIS interface (version 10.2). Different datasets are used to create the model. The digital elevation model $($ DEM) with a resolution of $30 \times 30 \mathrm{~m}$ [Figure 3(a)] (ASTER Global Digital Elevation Map, n.d.) is used to define the watershed and delineate the sub-watersheds (in this study: 33 sub-watershed and area of 7,245 $\mathrm{km}^{2}$ ) and the river channel network [Figures $3(\mathrm{~d})$ ]. The daily precipitation and minimum/maximum temperature datasets from 
five weather stations are used for 30 years (1981-2010) to run the SWAT model. The maps soil (FAO, n.d.) [Figure 3(b)] and land use (The European Space Agency, n.d.) [Figure 3(e)] are introduced to specify a quantity of water on each hydrological response unit (HRU), and the DEM to derive slopes which are then divided into four classes $(5 \%$, $15 \%, 30 \%$ and upper of 30\%) [Figure 3(c)]. For the calibration and validation of the model, measured discharge from four hydrometric stations, provided by the National Agency of Water Resources (ANRH) are used at monthly scale for the period (1981 to 2010).

\subsection{Performance calibration and validation of SWAT model}

Calibration and validation of the SWAT and soil and water assessment tool calibration and uncertainty procedures (SWAT-CUP) models are performed by comparing simulated and measured river discharge. Sensitivity analysis and calibration are realised within SWAT-CUPC (Zettam et al., 2017; Yebdri et al., 2007; Abbaspour, 2014) using the sequential uncertainty fitting 2 (SUFI-2) algorithm (Abbaspour et al., 2004). SUFI-2 is known to identify an appropriate parameter set in a limited number of iteration (Grusson et al., 2017; Yang et al., 2008). Detailed documentation of the SUFI-2 algorithm can be found in Abbaspour et al. (2004). As recommended by Yang et al. (2008), 1,500 iterations of calibration are performed by SWAT-CUP for all hydrological stations in this study. The model is evaluated at a monthly scale and the Nash-Sutcliffe-efficiency (NSE) and $\mathrm{R}^{2}$ are chosen as the objective functions. The sensitivity analysis is produced via a one-at-a-time procedure (Abbaspour, 2014) for 15 parameters as shown in Table 4. The parameters CN2.mgt (curve number), ALPHA_BF.gw (base flow alpha factor) and GW_DELAY.gw (groundwater delay) are the most sensitive parameters, which imply that the soil conservation service (SCS) streamflow curve number and groundwater delay days control significantly the streamflow.

The hydrological modelling is proceeded by the application of the SWAT hydrological model. The Tafna project is calibrated and validated by the SWAT hydrological model, at the monthly scale, for the period (1981-1995, 1996-2010) respectively, including the three years of warm-up period for calibration period (Table 5). The correlation between observed and simulated discharge is from satisfactory (station $\mathrm{C}$ with NSE $=0.54$ ) to very good (station D with NSE $=0.84$ ). On the other hand, during the validation, the correlation at station A is unsatisfactory (NSE $=0.21$ ). Similar results are found at this station by Zettam et al. (2017) who noted the influence of domestic and industrial wastewater from the major cities of Tlemcen and Maghnia in Algeria and Oujda in Morocco (Zettam et al., 2017).

For the calibration of the model, the annual hydrological balance is determined as $314 \mathrm{~mm}$ for precipitation, 1,256 $\mathrm{mm}$ for potential evapotranspiration, and $18.6 \mathrm{~mm}$ for surface runoff, which values are close to the reference values provided by ANRH (ANRH, 2003a, 2003b, 2003c). 
Table 4 Calibrated parameter values with a ranking of the most sensitive parameters (rank $1=$ most sensitive)

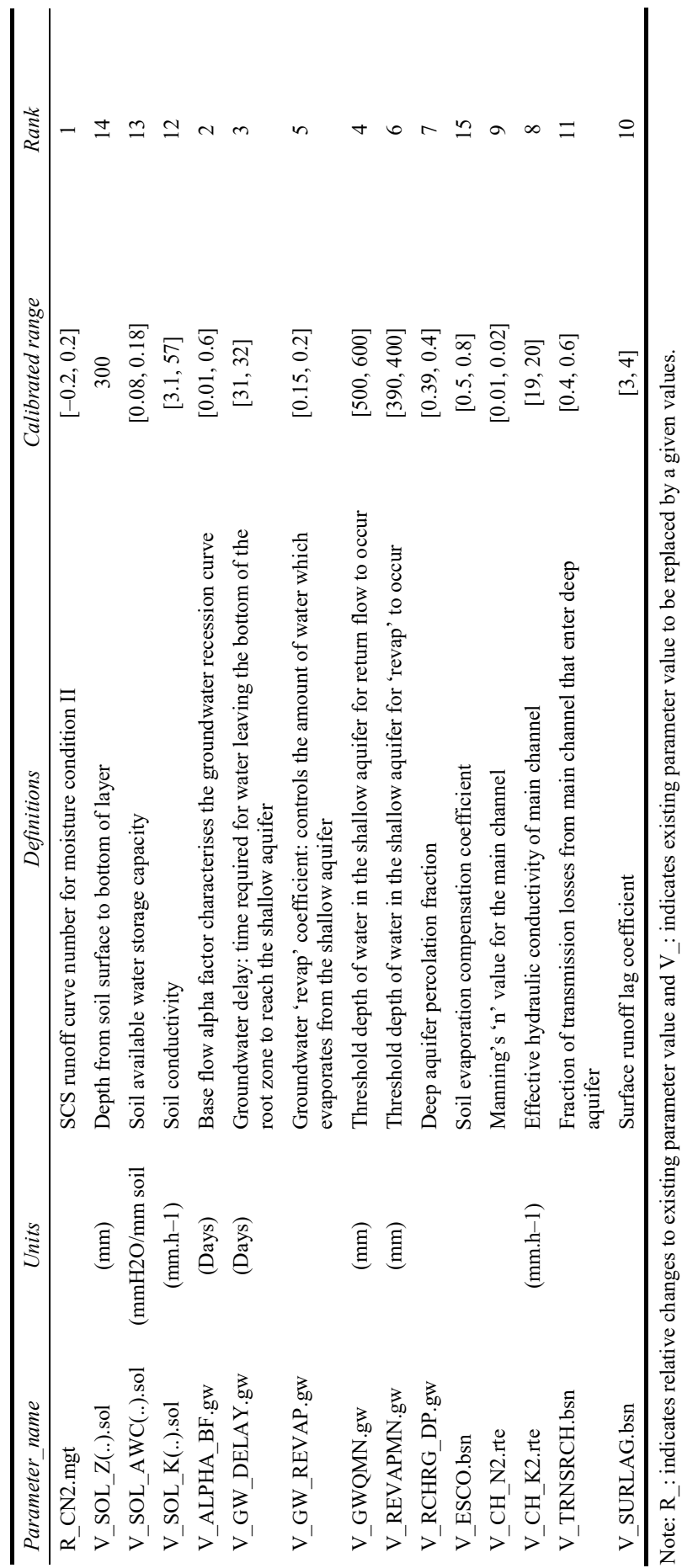


Table 5 Calibration and validation statistical values of NSE and $\mathrm{R}^{2}$ with performance rating of the NSE

\begin{tabular}{lccccccc}
\hline \multirow{2}{*}{ Stations } & \multicolumn{3}{c}{ Calibration (1981-1995) } & & \multicolumn{3}{c}{ Validation (1996-2010) } \\
\cline { 2 - 3 } \cline { 7 - 8 } & $N S E$ & $R^{2}$ & Performance rating & & NSE & $R^{2}$ & Performance rating \\
\hline A & 0.61 & 0.65 & Satisfactory & & -0.30 & 0.21 & Unsatisfactory \\
B & 0.62 & 0.69 & Good & & 0.65 & 0.71 & Good \\
C & 0.52 & 0.54 & Satisfactory & & 0.54 & 0.58 & Satisfactory \\
D & 0.83 & 0.84 & Very good & & 0.66 & 0.70 & Good \\
\hline
\end{tabular}

Source: Nash and Sutcliffe (1970)

\subsection{Performance of bias correction methods}

A reference period (1981-2000) is selected from the past period of the climatic and hydrologic datasets to apply the bias-correction methods.

The performance of bias-correction methods is carried out in two ways. The first one is to compare, at a monthly scale (January for winter and July for summer), the bias-correction methods (LS, LOCI, DM for precipitation and LS, VS, DM for temperature) of the ten RCM outputs ensemble with the observations and the uncorrected version of RCMs outputs using the boxplots (Figures 4 and 6). The second way is to compare, at a daily scale, the 95th percentile, the standard deviation (SD) and the mean values of the ten RCMs outputs bias-corrected by all of the methods with observations and uncorrected version of the ten RCMs (Figures 5, 7 and 8).

For river discharge, and to validate the bias-correction methods, nine combinations of bias-correction methods (precipitation-temperature: LS-LS, LS-VS, LS-DM, LOCI-LS, LOCI-VS, LOCI-DM, DM-LS, DM-VS and DM-DM) of precipitations and minimum/maximum temperature are introduced into the SWAT model to provide nine combinations of discharge. The discharges calculated with the nine combinations of bias-corrections methods are presented by boxplots and compared to the observations and uncorrected version of the RCM outputs (Figure 9). The second way is to compare, at monthly scale, the 95th percentile and the mean discharge, for the ten RCMs with observations and uncorrected version of the ten RCMs (Figure 10).

\section{Results}

\subsection{The bias-correction for RCM outputs of Cordex-Africa in North-Western Algeria}

The three methods of bias-correction used in this study (LS, DM: DM, LOCI) are able to reduce the bias of the ten raw RCM outputs of precipitation and temperature during summer and winter at five stations during the reference period (1981-2000) (Figure 4). Uncorrected RCM outputs (raw) strongly over-estimate precipitation during summer (July), which implies that the bias is significantly high during the dry season when the level of precipitation is very low for both observed and corrected datasets. The performance of the three bias-correction methods is suitable at all the stations, except at station 5, where the precipitation is over-estimated for the three bias-correction methods 
in winter (January). Maximum precipitation values at this station reaches $60 \mathrm{~mm}$ for observations but 110, 120, and $115 \mathrm{~mm}$ after correction with LS, DM and LOCI methods, respectively, because the bias between the maximum of the observations and uncorrected version is already lower than at the other stations. The estimation of the third quantile and minimum values (station 5) is however good compared to observations.

Figure 4 Comparison of precipitation datasets between observations (obs), the uncorrected version of the ten models (raw), and the corrected versions using four different bias-correction methods (LS, DM, LOCI) at each station (a) during winter (January) and (b) during summer (July) (see online version for colours)
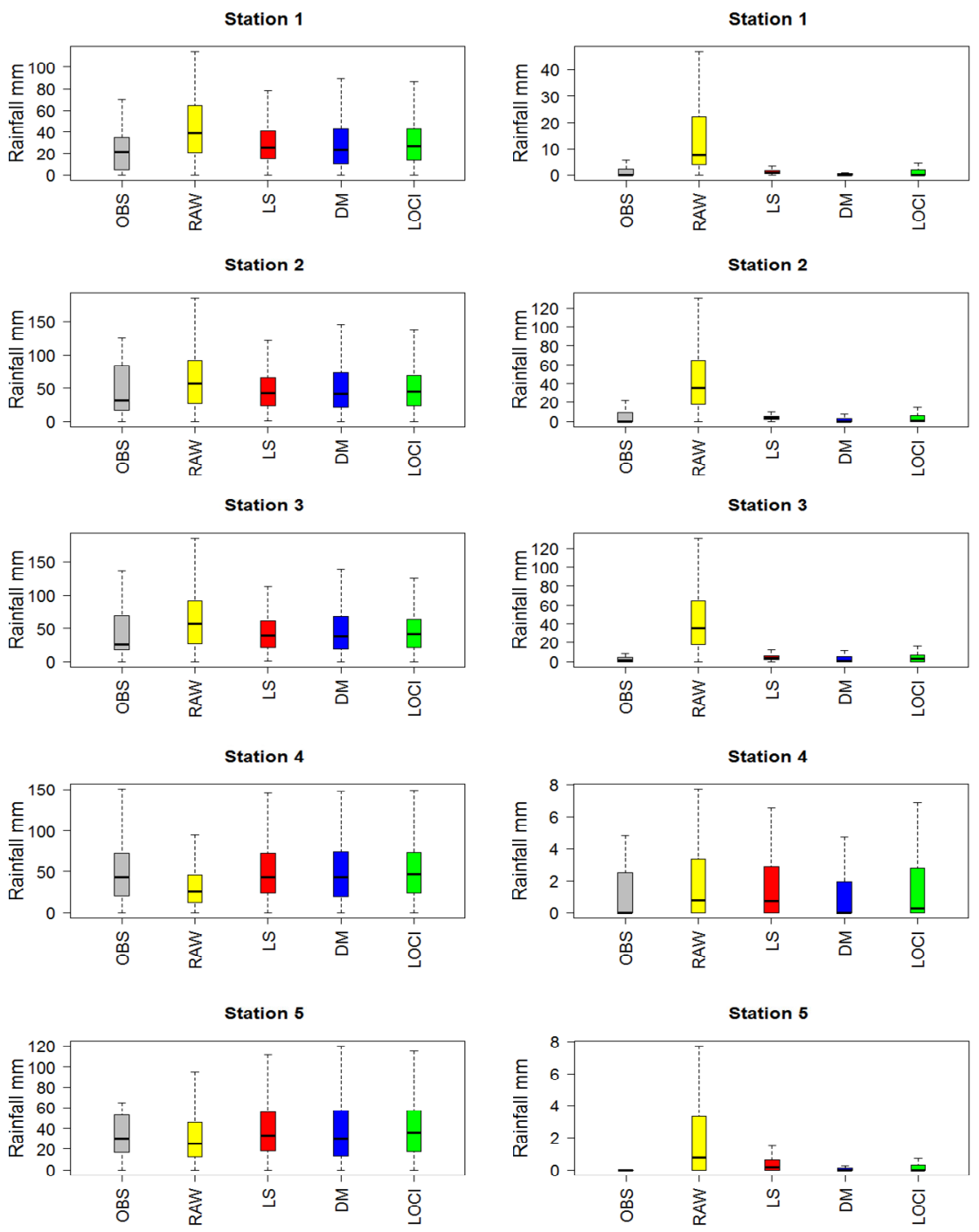

(a)

(b) 
Figure 5 Daily mean, P95 and SD of precipitation for bias-corrected RCMs, raw (uncorrected) RCMs and observed data for the reference period (1981-2000) (see online version for colours)
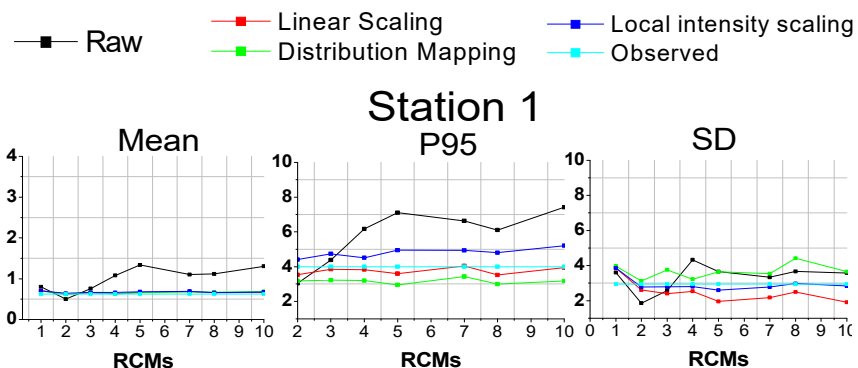

Station 2
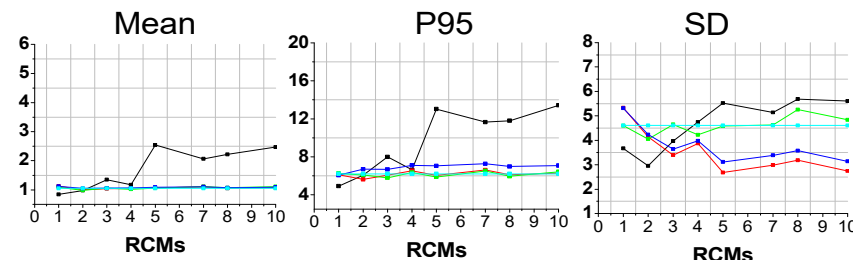

Station 3

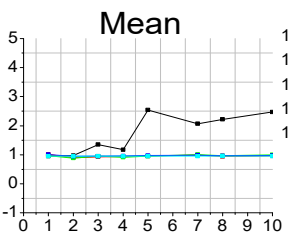

RCMs

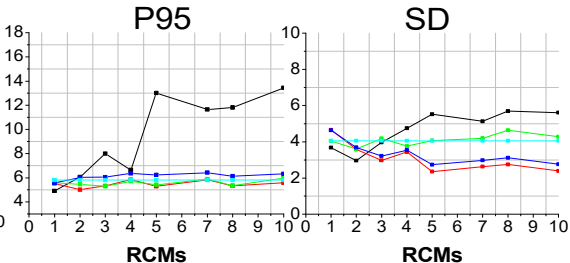

Station 4

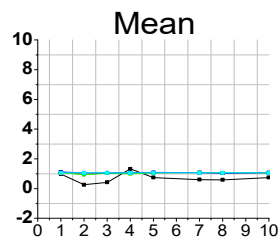

P95
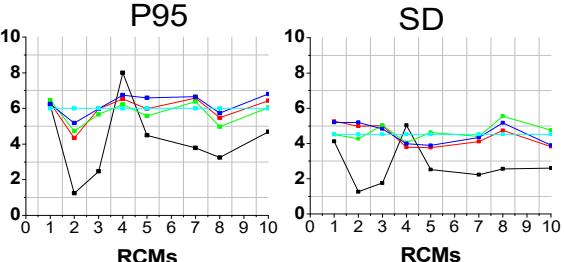

Station 5

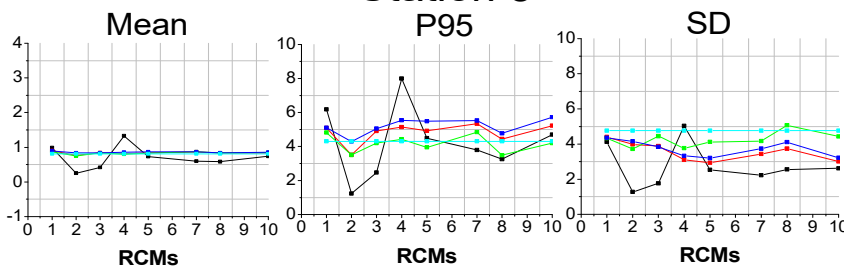

Note: The numbers [1 to 10] indicate the models: [EC-EARTH-CCLM4-8-17,

IPSL-CM5A-MR-RCA4, CCCma-CanESM2-RCA4, CNRM-CM5-CCLM4-8-17, CNRM-CM5-RCA4, EC-EARTH-RCA4, MIROC5-RCA4, MPI-ESM-LR-RCA4, NCC-NorESM1-M-RCA4 and NOAA/GFDL-ESM2M-RCA4], respectively. 
Figure 6 Comparison of minimum and maximum temperature datasets for observations (obs), uncorrected version of the ten RCM models (raw), and the bias-corrected RCM outputs using three different methods (LS, DM: DM, VS) (a) during winter (January) and

(b) during summer (July) (see online version for colours)

Station 1

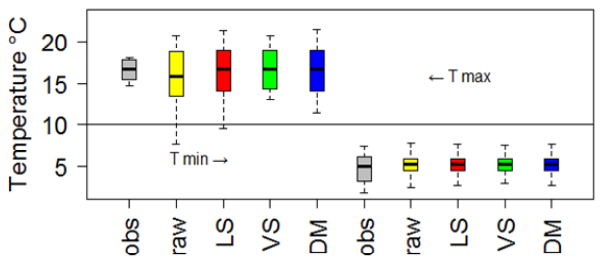

Station 2

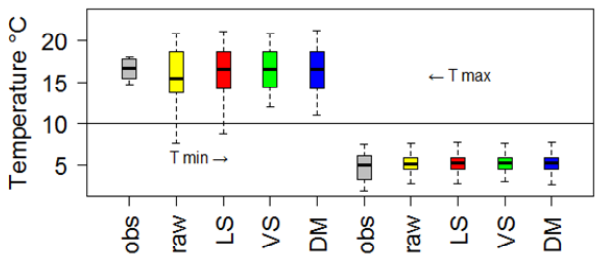

Station 3

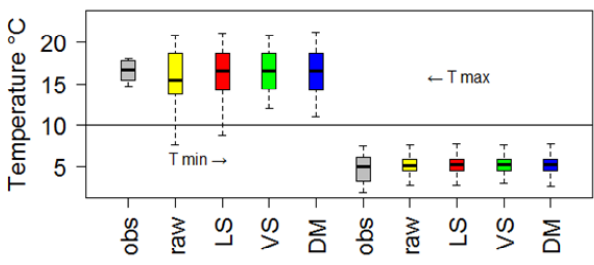

Station 4

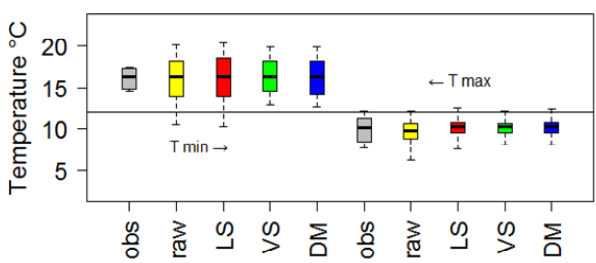

Station 5

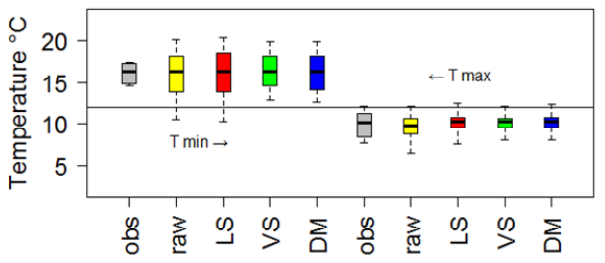

(a)
Station 1

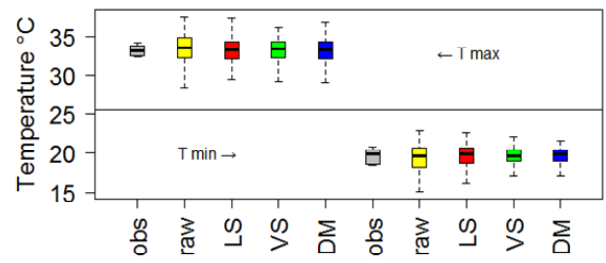

Station 2

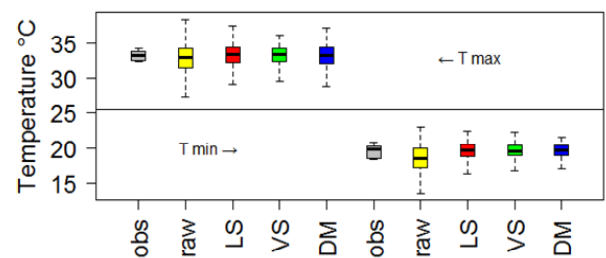

Station 3

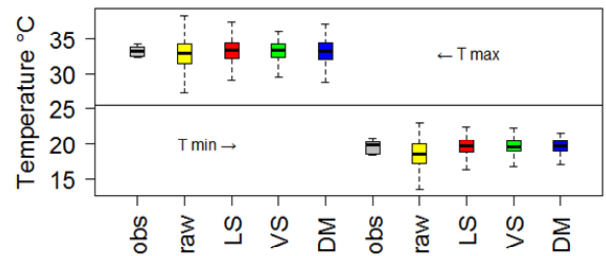

Station 4

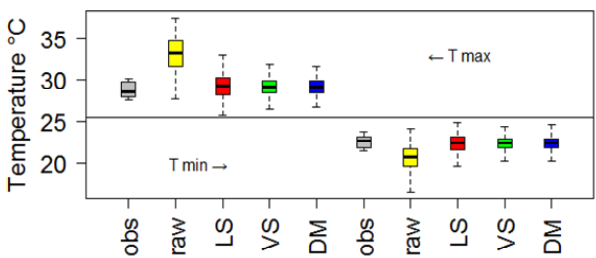

Station 5

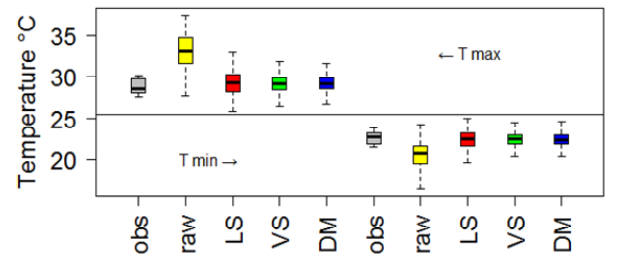

(b) 
Figure 7 Daily mean, P95 and SD of maximum temperature for bias-corrected RCMs, raw (uncorrected) RCMs and observed data for the reference period (1981-2000) (see online version for colours)

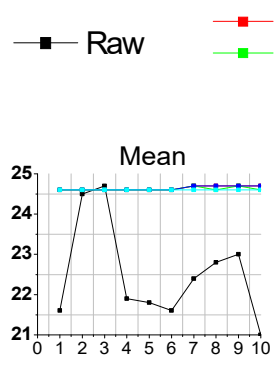

RCMs

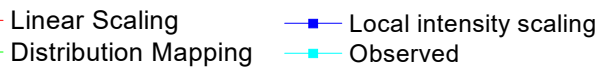

\section{Station 1}

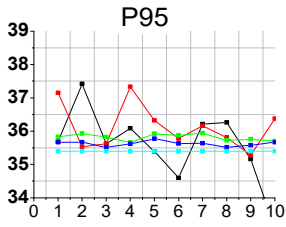

RCMs

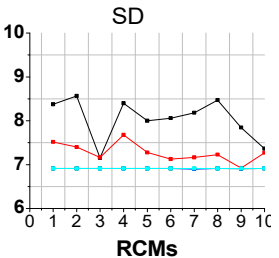

\section{Station 2}
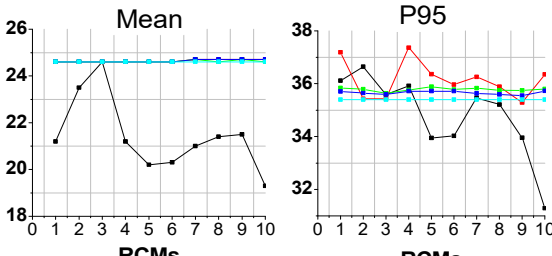

$\mathrm{RCMs}$

Station 3
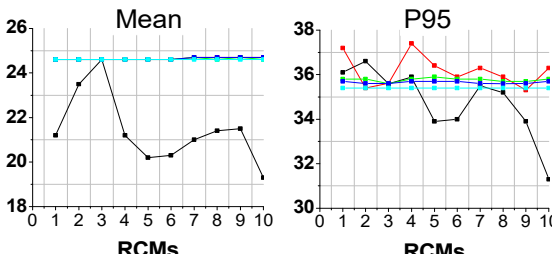

RCMs

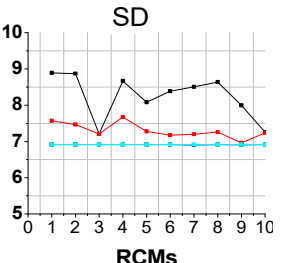

RCMs

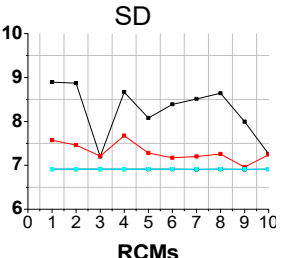

\section{Station 4}
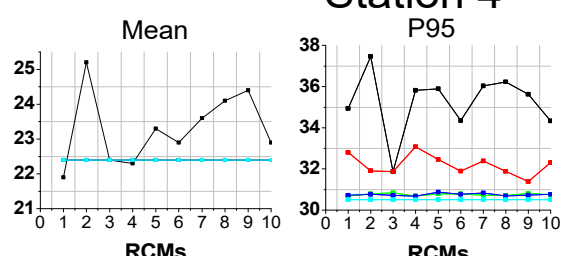

RCMs

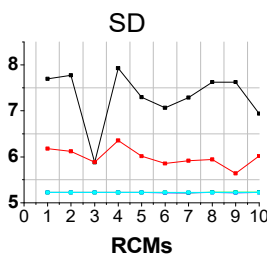

Station 5
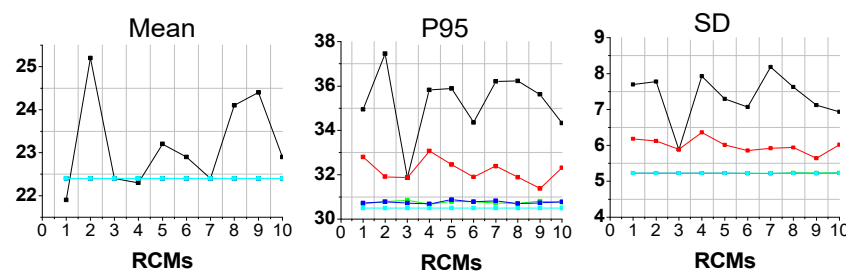

Note: The numbers [1 to 10] indicate the models: [EC-EARTH-CCLM4-8-17,

IPSL-CM5A-MR-RCA4, CCCma-CanESM2-RCA4, CNRM-CM5-CCLM4-8-17, CNRM-CM5-RCA4, EC-EARTH-RCA4, MIROC5-RCA4, MPI-ESM-LR-RCA4, NCC-NorESM1-M-RCA4 and NOAA/GFDL-ESM2M-RCA4], respectively. 
Figure 8 As Figure 7 for the minimum temperature (see online version for colours)

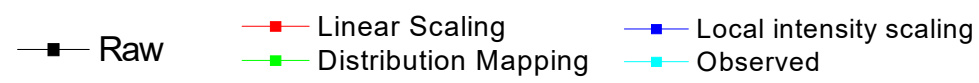

\section{Station 1}
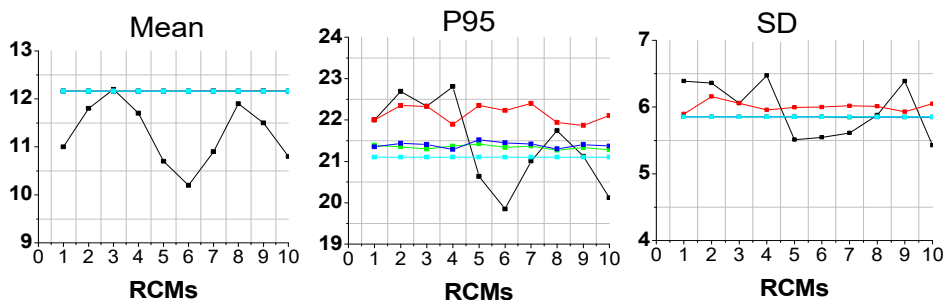

\section{Station 2}
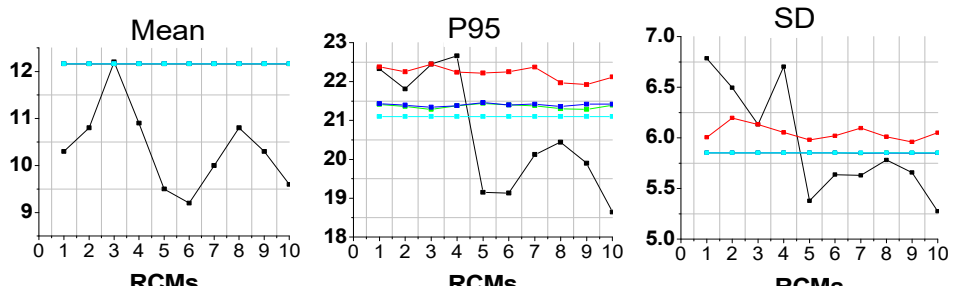

RCMs

RCMs

Station 3
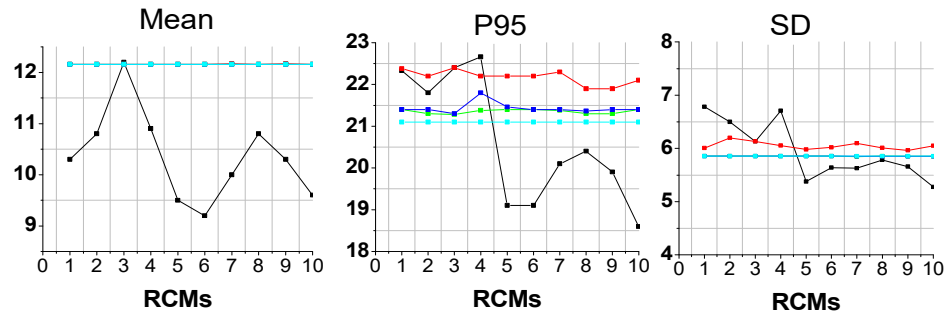

\section{Station 4}
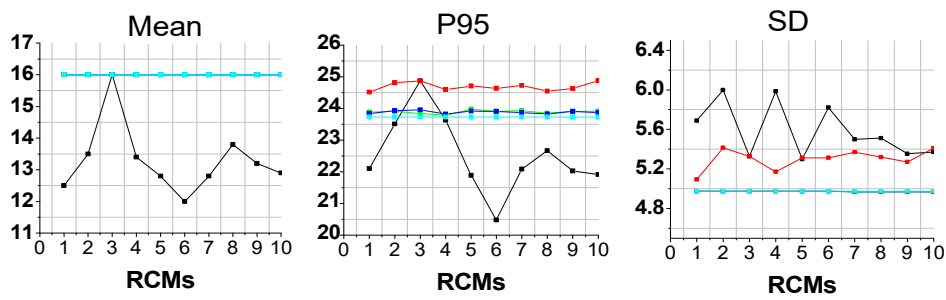

Station 5
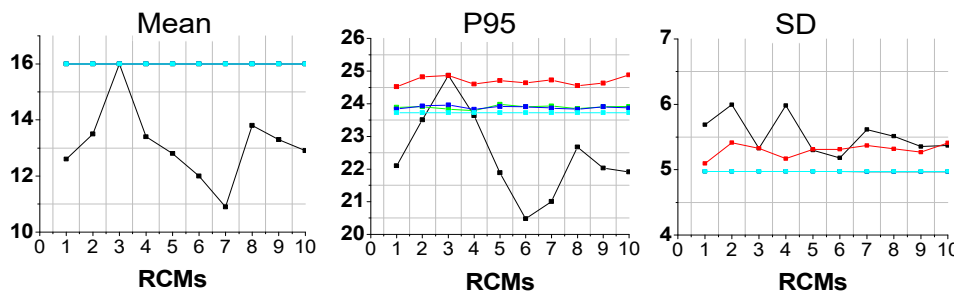
We then explore in more details the daily mean precipitation, 95th percentile (P95) and $\mathrm{SD}$ of each precipitation datasets between observations (obs), uncorrected version of the ten models (raw), and corrected ones using the three methods (LS, DM, LOCI) for the reference period (1981-2000) (Figure 5). Daily mean precipitations show that the three bias-correction methods correct well the bias of the RCMs outputs. The mean values of the three methods (LS, DM and LOCI) are similar to the observed mean precipitation, contrary to the uncorrected RCM outputs. We take into consideration the slight bias between uncorrected and observed datasets of these RCMs:

1 EC-EARTH-CCLM4-8-17

2 IPSL-CM5A-MR-RCA4

3 CCCma-CanESM2-RCA4

4 CNRM-CM5-CCLM4-8-17.

On the other hand, the 95th percentile and the SD show a difference between the methods of bias-correction, with a bias ranging between 0.01 and $1.66 \mathrm{~mm}$ for the RCM corrected with the three methods of bias-correction, but between 0.14 and $10.46 \mathrm{~mm}$ for uncorrected RCMs datasets. Among these methods, the DM method is the most performant with a bias of [0.02-1.27] $\mathrm{mm}$ with observations at all the stations, except station 1. At station 1, the LS method is the most efficient method with a bias of [0.04-0.48] mm.

Figure 6 shows the comparison of minimum/maximum temperature datasets between observations (obs), uncorrected version of RCMs (raw), and the corrected versions using three different methods (LS, DM: DM and VS) during winter (January) and summer (July) at each station. The results show a good accordance between model datasets and observations. The temperature median using the three methods of bias-correction is close to the observed data in January with $[15-16]^{\circ} \mathrm{C}$ and $[5-10]^{\circ} \mathrm{C}$ for the maximum and minimum temperature, respectively, and in July with $[28-33]^{\circ} \mathrm{C}$ and $[20-23]^{\circ} \mathrm{C}$ for the maximum and minimum temperature, respectively.

Figures 7 and 8 show statistical values to evaluate the bias-correction of the ten daily minimum/maximum temperatures of RCM datasets for the reference period (1981-2000). The 95th percentile and SD show a small difference between the methods of bias-correction, compared to the observed datasets. The difference varies between $[0.06-0.7]^{\circ} \mathrm{C}$ and $[0.17-0.54]^{\circ} \mathrm{C}$ for DM and LOCI methods for daily minimum and maximum temperature, respectively; between $[0.77-1.35]^{\circ} \mathrm{C}$ and $[0.88-2.57]^{\circ} \mathrm{C}$ for $\mathrm{LS}$ method; and between $[1.14-3.25]^{\circ} \mathrm{C}$ and $[1.2-6.96]^{\circ} \mathrm{C}$ for uncorrected RCMs datasets. The DM and LOCI methods are the most efficient to reduce the bias.

\subsection{Hydrological results}

We apply the precipitation and minimum/maximum temperature datasets corrected for bias with the three methods to force the SWAT hydrological model of the Tafna basin. The outputs of the SWAT model are obtained from nine combinations of bias-correction methods [DM-DM: DM (for precipitation)-DM (for temperature), DM-LS, DM-VS, LS-DM, LS-LS, LS-VS, LOCI-DM, LOCI-LS and LOCI-VS]. The results are presented at a monthly scale (Figure 9). In this part, we refer to the hydrometric stations (A, B to D) 
to evaluate the river discharge calculated by SWAT model from nine combinations of bias-corrected precipitation and temperature datasets.

Figure 9 Comparison of monthly river discharge outputs obtained from SWAT simulations forced with observed meteorological datasets (Ref), with uncorrected RCMs outputs $(\mathrm{RCM})$, and with nine combinations of bias correction methods for precipitation and temperature of the ten RCM datasets, for January and July (see online version for colours)

JANUARY

STATION A

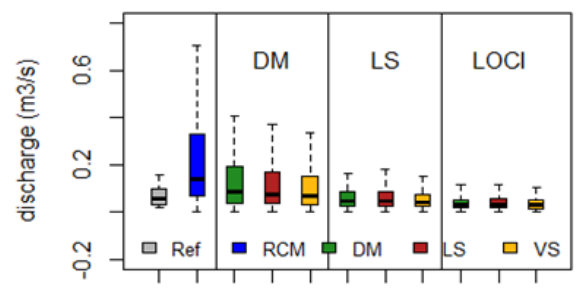

STATION B

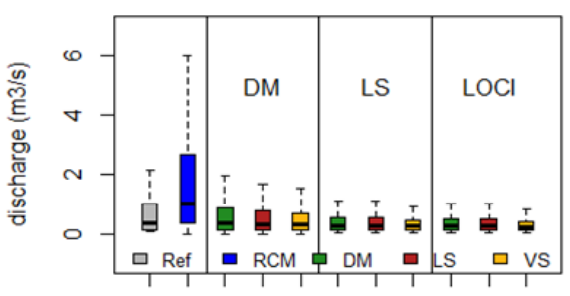

STATION C

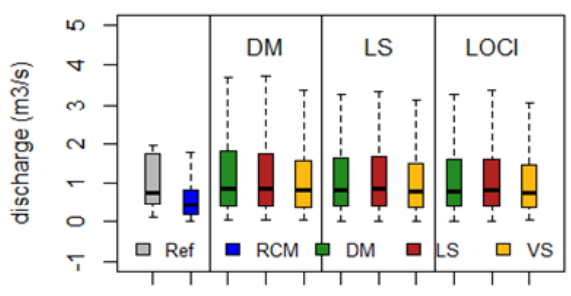

STATION D

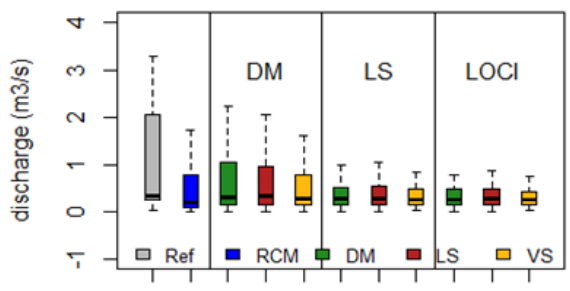

JULY

STATION A
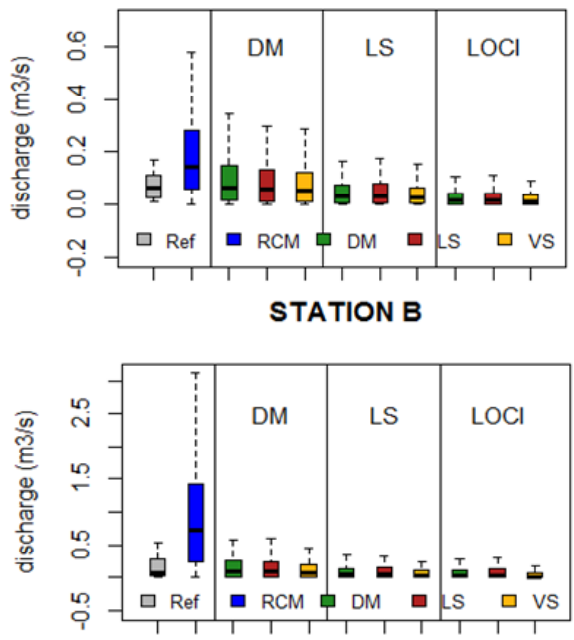

STATION C

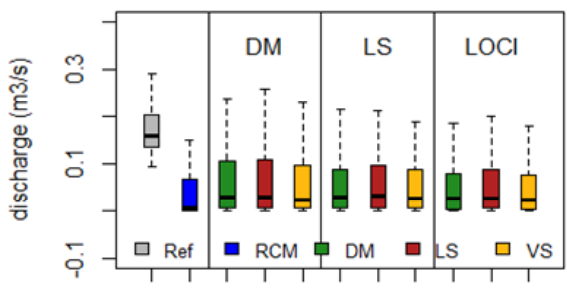

STATION D

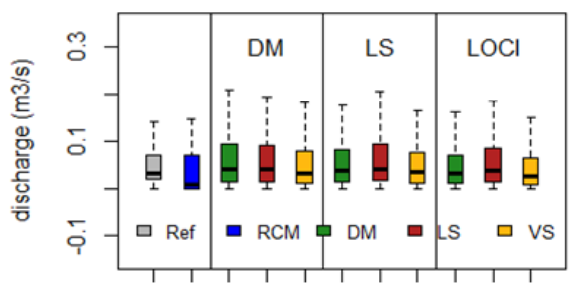

Note: The coloured boxes (green: DM, brown: LS and yellow: VS) illustrate the bias correction method for temperature for each correction method for precipitation (DM, LS and LOCI). 
Figure 10 Comparison of monthly river discharge obtained from SWAT simulations forced with observed meteorological datasets (ref flow), with uncorrected RCMs outputs (raw flow), and with nine combinations of bias-corrected precipitation and temperature of the ten RCM outputs, for January and July during the reference period (1981-2000) (example. DM-DM: DM method for precipitation; DM method for temperature) (see online version for colours)
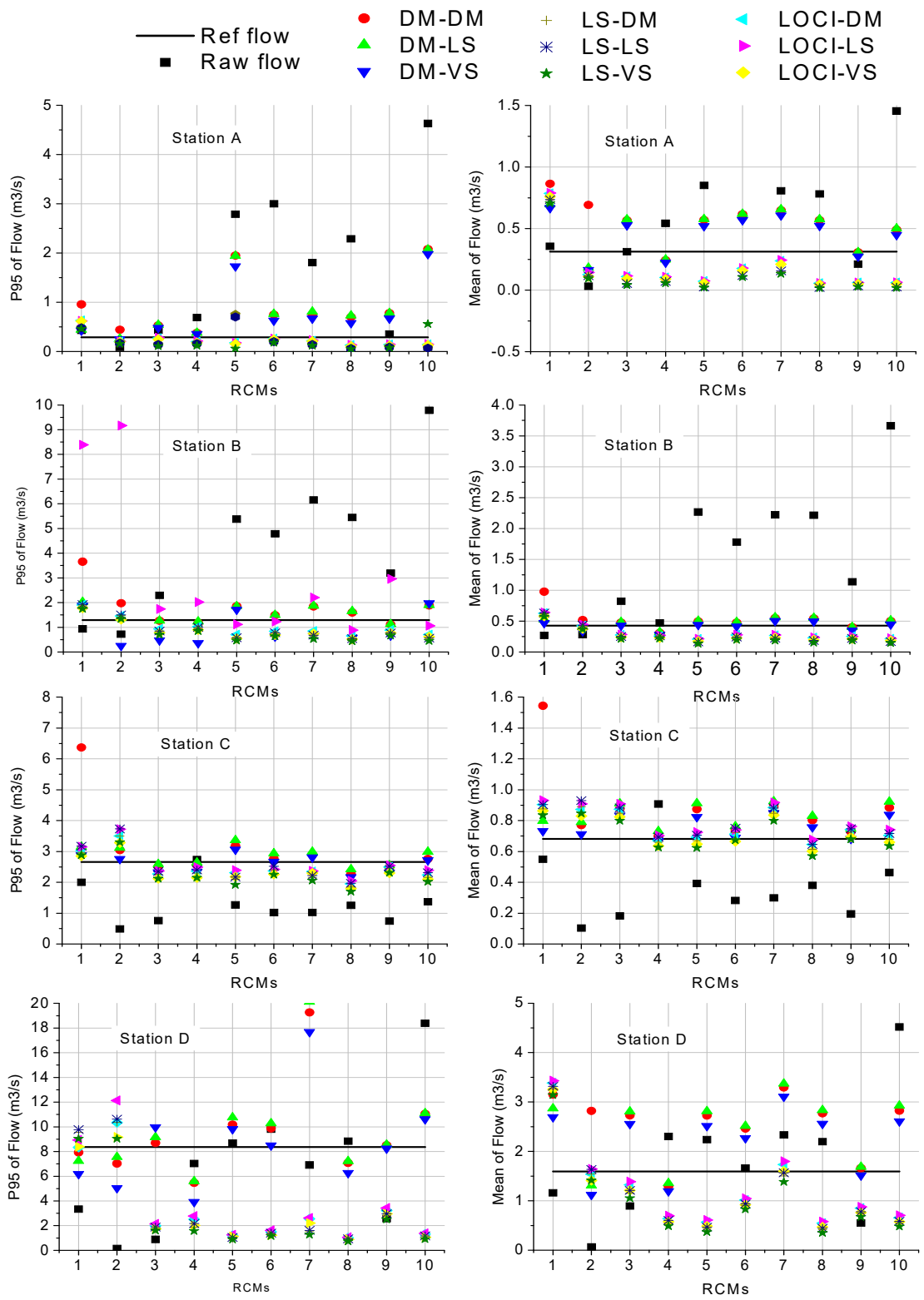

Note: The numbers [from 1 to 10] are respectively the models:

[EC-EARTH-CCLM4-8-17, IPSL-CM5A-MR-RCA4, CCCma-CanESM2-RCA4, CNRM-CM5-CCLM4-8-17, CNRM-CM5-RCA4, EC-EARTH-RCA4, MIROC5-RCA4, MPI-ESM-LR-RCA4, NCC-NorESM1-M-RCA4 and NOAA/GFDL-ESM2M-RCA4]. 
Figure 11 Comparison of the mean inter-annual river discharge (for a period of 20 years) of the NCC-NorESM1-M-RCA4 model outputs uncorrected and corrected by the combination of DM-DM methods over the period (2000-2100) (see online version for colours)
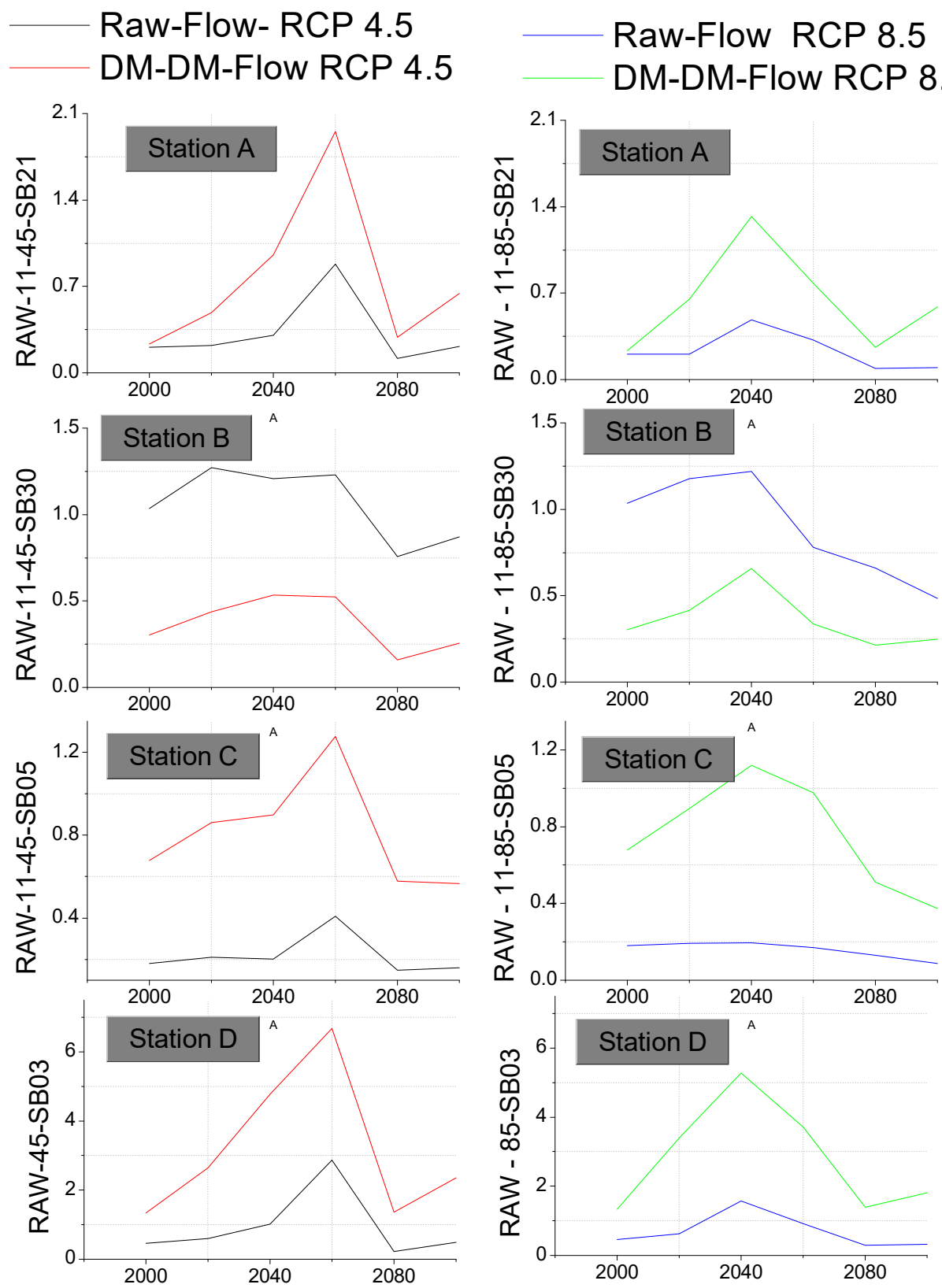

Note: With $2000=$ period from 1981 to $2000,2020=$ from 2000 to $2020, \ldots, 2100=$ 2080 to 2100 . 
Figure 12 Future evolution of annual precipitation, discharge and minimum/maximum temperature based on the ten bias corrected RCMs under RCPs 4.5 and 8.5 at the outlet station (station 5/D), from the historical period $(2000=$ from 1981 to 2000$)$ to 2100 with an interval of 20 years (see online version for colours)

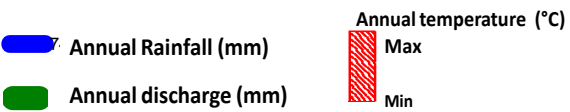

RCP 4.5

RCP 8.5

RCP 4.5

RCP 8.5
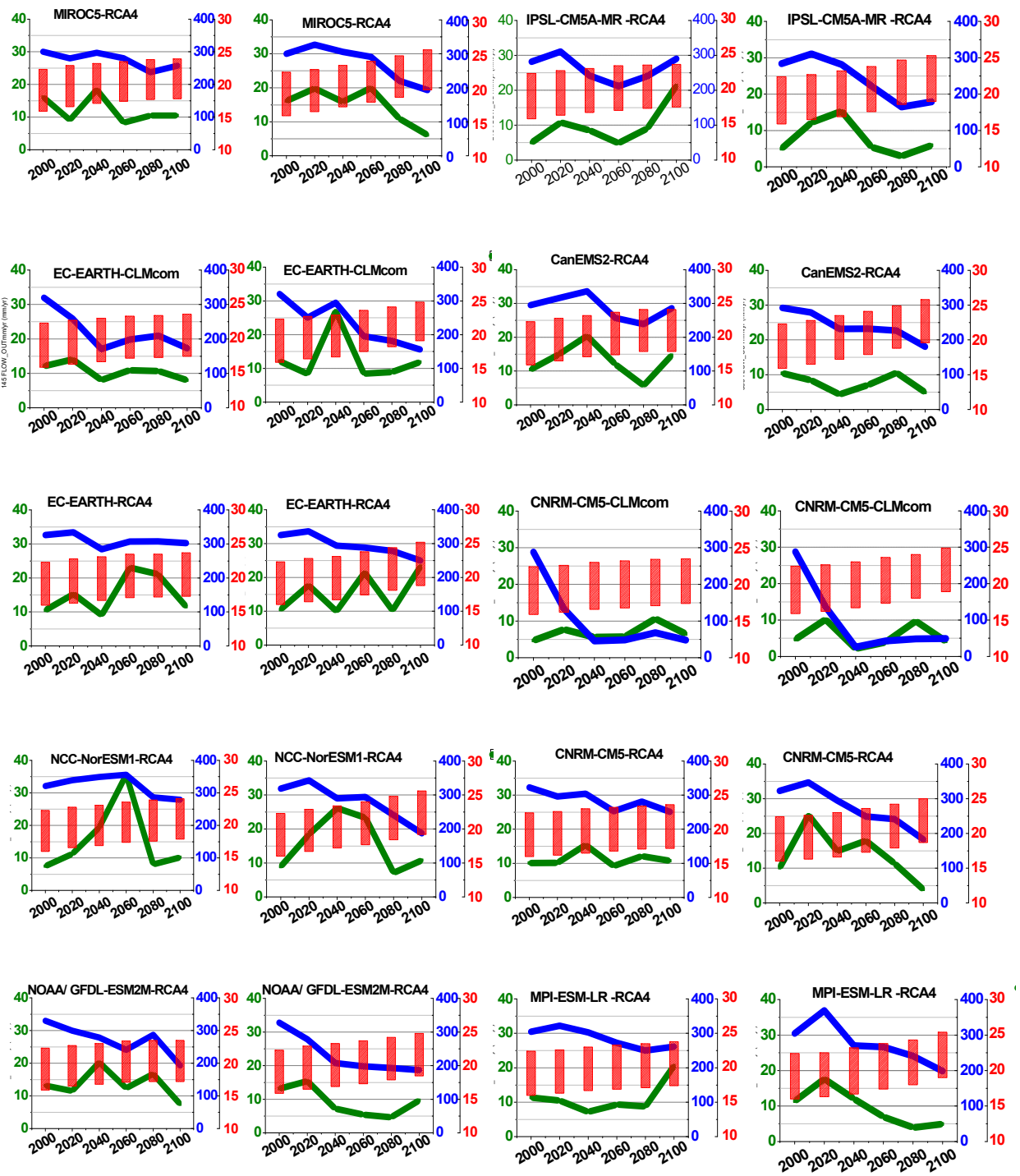

The monthly river discharges resulting from the nine combinations of bias-corrected precipitation and temperature of the ten RCM datasets (Figure 9) show that the performance of bias-correction methods is suitable contrary to applications using the 
uncorrected RCM outputs. The minimum, the median, and the 25 th quantile of river discharge are very close to the reference discharge, at all stations, except station $\mathrm{C}$ in July. LS and DM methods for precipitation perform well at stations A, and B and D, respectively. At station $\mathrm{C}$, all the methods perform poorly. We notice that the bias-correction for temperature has a lower effect than of precipitation correction on river discharge simulation.

A detailed interpretation of bias-correction for each RCM is represented in Figure 10. The river discharge is obtained from the nine combinations of bias-correction methods for precipitation and temperature. The bias between river discharge calculated with RCMs outputs and the reference discharge is generally reduced after correction for the ten RCMs (Figure 10). The mean monthly discharges resulting from the nine combinations range between 0 and $1.0 \mathrm{~m}^{3} \cdot \mathrm{s}^{-1}$ while the monthly reference discharge shows mean values of $0.3,0.45$ and $0.69 \mathrm{~m}^{3} \cdot \mathrm{s}^{-1}$ at stations $\mathrm{A}, \mathrm{B}$ and $\mathrm{C}$, respectively. The station $\mathrm{D}$ has values ranging between 0.2 and $3 \mathrm{~m}^{3} \cdot \mathrm{s}^{-1}$ similar to the reference mean discharge of $1.6 \mathrm{~m}^{3} . \mathrm{s}^{-1}$. For the mean monthly discharge, the three combinations using DM correction for precipitation have the most suitable hydrological response for the RCMs (4 and 9), (3 and 5-10), (4, 6 and 9), (9) at the stations A, B, C and D, respectively. The same response is given for the combinations using LOCI and LS correction for precipitation at station $\mathrm{C}$.

The 95th percentile of the monthly discharge of the nine combinations ranges between 0.3 and $2.7 \mathrm{~m}^{3} \cdot \mathrm{s}^{-1}$ at stations $\mathrm{A}, \mathrm{B}$ and $\mathrm{C}$, and between 1 and $12 \mathrm{~m}^{3} \cdot \mathrm{s}^{-1}$ at station $\mathrm{D}$ compared to the 95th percentile of the reference monthly discharge of $8.5 \mathrm{~m}^{3} \cdot \mathrm{s}^{-1}$.

The most suitable combinations to model the mean reference river discharge are DM and LOCI for precipitation and VS for temperature. In the case of 95th percentile, the most appropriate combinations are (LOCI, LS for RCMs: 1-10), (DM: 5-10), (DM: 2-4 and 6-10), (DM: 3, 7, 9) at stations A, B, C and D, respectively.

The NCC-NorESM1-M-RCA4 model outputs corrected for the bias with the combination DM-DM are chosen among the ten RCMs and the nine correction combinations to study hydrological impacts, as it results in the lowest precipitation and temperature bias at the four hydrological stations.

Figure 11 presents the comparison between the mean inter-annual discharge using the uncorrected and DM-DM corrected (with the DM-DM combination) NCC-NorESM1-M-RCA4 model outputs over the period (2000-2100) under the two RCPs 4.5 and 8.5. The periods 2020-2040 and 2040-2060 show an increase in river discharge, and a decrease starting from 2060, with RCP 4.5. The decrease of discharge appears earlier and starts in 2040 with RCP 8.5. A similar temporal dynamic of the discharge decrease and increase is observed with the uncorrected and bias-corrected versions of RCMs, but with a large difference in discharge intensity between the uncorrected and corrected RCM outputs. The evolution of the three environmental variables (precipitation, minimum/maximum temperature and discharge) for the ten RCMs is shown in Figure 12 over the period 1981-2100 with an interval of 20 years. The increase of minimum/maximum temperature is shown for the ten RCMs until 2100, and the decrease in precipitation and discharge appears from 2040. The decrease in precipitation and discharge is more important with RCP 8.5 than with RCP 4.5. 


\section{Discussion}

\subsection{The use of bias correction methods on RCM outputs of Cordex-Africa to study climate change impacts in Northern Africa}

Precipitation outputs from some RCMs are highly biased in the Mediterranean region such as CLMcom and SMHI, with biases generally ranging between $-40 \%$ and $+80 \%$ compared to observations (Kotlarski et al., 2014; Panthou et al., 2016; Vautard et al., 2013). Some methods of bias-correction are proposed to adjust RCM outputs to analyse climate change, from the simple LS method to the sophisticate nonlinear one DM.

The CMhyd software is used because it is tailor-made to extract bias-correct RCMs outputs and prepare simulated climate variables for climate change impact studies with the SWAT model (Senent-Aparicio et al., 2017; Brouziyne et al., 2018; Xiang et al., 2018). However, some studies using CMhyd software have directly applied a DM method (Senent-Aparicio et al., 2017; Xiang et al., 2018) or a LS method (Brouziyne et al., 2018) for adjusting precipitation, without evaluating the performance of the method.

In this study, three methods of bias-correction for precipitation (LS, DM, LOCI), and three for temperature (LS, DM, VS), are tested for adjusting Cordex-Africa RCMs for the reference period (1981-2000). These linear methods (LS and LOCI) (Schmidli et al., 2006; Leander and Buishand, 2007) and nonlinear DM methods (Ahmed et al., 2015; Fang et al., 2015; Luo et al., 2018; Teutschbein and Seibert, 2012; Kim et al., 2016; M'Po et al., 2017; Vithlani and Rank, 2016) give acceptable reduction of bias for all the Cordex-Africa RCMs used in this study.

However, for precipitation, the nonlinear DM method leads to the lowest bias at most of the stations, as observed in other studies in different regions and climates (Senent-Aparicio et al., 2017; Luo et al., 2018; Teutschbein and Seibert, 2012). For the minimum/maximum temperature, the DM method and the VS method, an extension of the LS method, reduce the bias better than the LS method, confirming the results of numerous studies (Luo et al., 2018; Teutschbein and Seibert, 2012; Szabó-Takács et al., 2019).

When combining the bias-correction methods of precipitation and temperature, our results shows that the method chosen to correct temperature bias only slightly influences the calculation of river discharge. The selection of the appropriate bias-correction method to correct precipitation datasets is the most important to obtain river discharge consistent with observations.

\subsection{Hydrological impact of the use of bias correction of RCM outputs in the reference period}

Before exploring the hydrological impact of the use of bias-correction on RCM outputs, it is important to evaluate the calibration and validation of the SWAT model on the Tafna basin. The NSE statistical criteria for model calibration and validation are satisfactory or even good to very good at the outlet of the basin. The NSE is only unsatisfactory at station A (NSE $=-0.30$ ), which was already observed in the study of Zettam et al. (2017) due to the influence of the anthropogenic wastewater provided by domestic and industrial of the cities Tlemcen and Maghnia in Algeria and Oujda in Morocco. Except this station, the statistical criteria of the calibration and validation are close to those obtained in different semi-arid regions: in the same basin (Tafna) with values of Nash-Sutcliffe 
ranging between 0.42 and 0.75 (Zettam et al., 2017), in the Hamadan-Bahar basin in Iran (Nerantzaki et al., 2015) with values from 0.33 to 0.77 , and in the Medjerda basin with values from 0.31 to 0.65 (Bouraoui et al., 2005).

Some studies using CMhyd software have applied directly a DM method (Senent-Aparicio et al., 2017; Xiang et al., 2018) or a LS method (Brouziyne et al., 2018) for adjusting precipitation, without evaluating the performance of the method. To evaluate bias-correction methods and their impact on hydrology, we compare hydrological outputs obtained using the RCMs outputs as forcing to the SWAT model, under the two versions, the uncorrected and the bias-corrected datasets for the reference period (Figures 9 and 10).

The inter-annual river discharges in the Tafna basin obtained using the raw precipitation and temperature datasets are over-estimated (except at station C), but the river discharges obtained with bias-corrected RCMs outputs are much closer to the observed river discharge. The forcing of the hydrological model by the bias-corrected RCMs outputs leads to improve the modelling of the river discharge during the reference period.

The correction of precipitation bias is essential, as our aim is to investigate hydrological impacts in the future. Muerth et al. (2013) highlights that bias-corrected RCMs, before using them in hydrological models, provide closer representation of hydrograph to observations. The dynamic of the river discharge is similar with the uncorrected and the bias-corrected precipitation datasets, but the bias is significantly decreased after bias correction (Figure 11), which confirms the need of correcting precipitation bias for hydrological applications.

Even if some studies advise the direct use of RCM outputs because bias correction might lead to misleading results (Luo et al., 2018; Maraun et al., 2010; Kjellström et al., 2011; Thomas et al., 2012), bias-correction is generally recommended to reduce bias between observed and simulated climate variables (Lenderink et al., 2007; Wilby et al., 2000; Brouziyne et al., 2018), especially to study hydrological impacts (Bernstein et al., 2007). Reducing the bias of the original RCM outputs leads to a better representation of river discharge at the outlet of the Tafna basin, indicating that the correction of precipitation bias is essential to investigate hydrological impacts in the reference period. Our results confirm that the bias-correction of RCMs, before using them in hydrological models, provide a closer representation to the observed hydrograph (Bernstein et al., 2007).

\subsection{Future projections of climatic and hydrological variables}

The increase of minimum/maximum temperature has already been observed for decades, and this warming is estimated at $+0.2^{\circ} \mathrm{C}$ per decade (Bernstein et al., 2007). Our results show an increase of approximately $+0.3^{\circ} \mathrm{C}$ per 20 years under RCP 4.5 and $+0.5^{\circ} \mathrm{C}$ under RCP 8.5 (Figure 12) which confirms the results of the IPCC (Bernstein et al., 2007). These trends are also close to those found in Northern Africa under Cordex in 'MENA' (the Middle East and North Africa) and in Europe (Zeroual et al., 2018; Ahmadalipour and Moradkhani, 2018; Dosio and Panitz, 2016; Jacob et al., 2014). This increase of minimum/maximum temperature leads to the warming of the region, and the associated decrease in precipitation leads to the intensification of droughts.

In the Mediterranean region, the decrease in rainfall is estimated at $-20 \%$ and $-30 \%$ under RCPs 4.5 and 8.5, respectively (IPCC Working Group I et al., 2013; 
Brouziyne et al., 2018; Schilling et al., 2012; Philandras et al., 2011; Solomon and Intergovernmental Panel on Climate Change, 2007). The ten RCMs evaluated in this study show an important decrease in precipitation for the quasi totality of the future period, with a more significant intensity under RCP 8.5 (-34\%) compared to the RCP 4.5 $(-25 \%)$. This confirms the results of Zeroual et al. (2018) in the North of Algeria using Cordex-Africa who mentions that aridification seems to be more important during the period 2045-2098. This decrease directly affects the discharge of the basin. This could reduce the period of filling dams, leading to an imbalance between water demand and supply, as shown in Figure 12.

The 4th IPCC Report (AR4, 2007) mentions that the river discharge might decrease until $-30 \%$ in the future for the Mediterranean region. Brouziyne et al. (2018) and Tramblay et al. (2013) obtain similar results in the region of Morocco. These results are complementary to our study, presenting a decrease of discharge using ten different combinations of GCM/RCM models. The decrease of river discharge starting in 2060 using RCP 4.5 and in 2040 with RCP 8.5 influences the availability of superficial and underground water resources. That could lead to droughts associated with heatwaves, which may later imply a decrease and even disappearance of fauna and flora. This may create an imbalance in water demand and supply, implying a negative effect on drinking water demand which represents the major part of water demand compared to irrigation of agricultural lands and industrial water abstraction. The river discharge decrease could also lead to a decrease in the stored useful reserve, and increase the water stress of this vulnerable region to drought.

The discharge decrease is more important under RCP 8.5, indicating that continuing emitting $\mathrm{CO}_{2}$ without stabilisation might lead to more severe impacts in the North of Africa. This highlights the need to stabilise $\mathrm{CO}_{2}$ concentration to avoid social-economic consequences in these semi-arid regions of the world.

This study gives additional information on climate change impacts in the Mediterranean region (Ruti et al., 2016; Zittis et al., 2019; Gan et al., 2016). The majority of Cordex RCMs suggest a significant increase in temperature (Zittis et al., 2019), throughout the future period. Zittis et al. (2019) notices that this projected regional arise of temperature is more pronounced than the global evolution. While most of the studies use RCMs outputs from the Med-Cordex project, this study provides an evaluation of the Cordex-Africa precipitation and temperature datasets. Our results confirm (Ruti et al., 2016; Zittis et al., 2019; Gan et al., 2016) the increase of temperature and decrease of precipitation in the future in the Tafna basin which is part of the Mediterranean region.

\section{Conclusions}

This work presented the evaluation of regional climatic model outputs of the Cordex-Africa project in the North-Western region of Algeria, the semi-arid Tafna watershed, which is known for its drought since the 1970s (Taibi et al., 2017; Meddi et al., 2010; Senent-Aparicio et al., 2017; Schilling et al., 2012). The purpose is to assess the future hydrological evolution of the region by using the ten RCM outputs of Cordex-Africa. These RCMs outputs are bias-corrected, by different methods on the reference period (1981-2000) at five stations, and the most adapted bias-correction method is selected. The more suitable bias-correction methods are DM and LOCI for precipitation, and DM and VS for temperature. The bias-correction of precipitation (more 
than temperature) has a considerable impact on inter-annual river discharge, without changing the behaviour of hydrological trend.

This study of the evaluation of climatic and hydrologic change on the Tafna basin contributes to improve knowledge about the increase of minimum/maximum temperature and the decrease of rainfall which affect the water resource of the region, and drive the drought.

The Tafna basin, a river basin with high water stress, is used to present a methodology to analyse and apply regional climatic model outputs for hydrological applications in river basins characterised by similar characteristics and problems.

The results of bias-correction of RCM outputs obtained in this study are in tune with previous studies in the Mediterranean region. We can consider these results as representative of semi-arid regions in North Africa and other regions having similar characteristics to the Tafna basin. The climatic evolution can be representative for the Mediterranean region, particularly the Northern Africa.

\section{Acknowledgements}

The authors wish to thank Algerian institutions (ANRH, Office National de Météorologie) for providing data series, Amina Mami's stay in France was made possible thanks to a scholarship from 'National Exceptional Program' (PNE-2017) awarded by the Ministry of Higher Education and Scientific Research of Algeria, The Laboratoire Ecologie fonctionnelle et Environnement is gratefully acknowledged for its support of this research project, Eleni Katragkou from the Cordex project group is thankfully acknowledged for her help for data collection. Thanks to Sabrina TAIBI and the AguaMod group.

Amina Mami, Djilali Yebdri, Sabine Sauvage and José Miguel Sánchez-Pérez conceived and designed the experiments, Amina Mami performed the experiments, Amina Mami, Mélanie Raimonet, Djilali Yebdri, Sabine Sauvage and José Miguel Sánchez-Pérez analysed the results, Amina Mami, Mélanie Raimonet, Djilali Yebdri, Sabine Sauvage and José Miguel Sánchez-Pérez wrote the paper, and Amin Zettam helped for preparing the SWAT model and the datasets collection.

\section{References}

Abbaspour, K.C. (2014) SWAT-CUP 2012: SWAT Calibration and Uncertainty Programs - A User Manual, Swiss Federal Institute Science and Technology, Eawag.

Abbaspour, K.C., Johnson, C.A. and van Genuchten, M.T. (2004) 'Estimating uncertain flow and transport parameters using a sequential uncertainty fitting procedure', Vadose Zone J., Vol. 3, pp.1340-1352 [online] https://doi.org/10.2136/vzj2004.1340.

Adnan, M., Kang, S., Zhang, G., Saifullah, M., Anjum, M.N. and Ali, A.F. (2019) 'Simulation and analysis of the water balance of the Nam Co Lake using SWAT model', Water, Vol. 11, p.1383 [online] https://doi.org/10.3390/w11071383.

Agence Nationale des Ressources Hydriques (ANRH) (1981) Daily Data Flow in the North of Algeria.

Ahmadalipour, A. and Moradkhani, H. (2018) 'Escalating heat-stress mortality risk due to global warming in the Middle East and North Africa (MENA)', Environ. Int., Vol. 117, pp.215-225 [online] https://doi.org/10.1016/j.envint.2018.05.014. 
Ahmed, K., Shahid, S., Harun, S. and Nawaz, N. (2015) 'Performance assessment of different bias correction methods in statistical downscaling of precipitation', Malays J. Civ. Eng., Vol. 27 [online] https://doi.org/10.11113/mjce.v27n0.416.

Amengual, A., Homar, V., Romero, R., Alonso, S. and Ramis, C. (2012) 'A statistical adjustment of regional climate model outputs to local scales: application to Platja de Palma, Spain', J. Clim., Vol. 25 [online] https://doi.org/10.1175/JCLI-D-10-05024.1.

AR4 (2007) AR4 Climate Change 2007: Synthesis Report [online] https://www.ipcc.ch/report/ ar4/syr/ (accessed 6 January 2020).

Arnold, J.G., Srinivasan, R., Gassman, P.W., White, M.J., Abbaspour, K.C., Santhi, C. et al. (2012) 'SWAT: model use, calibration, and validation', Am. Soc. Agric. Biol. Eng., Vol. 55 No. 5, pp.1491-1508.

ASTER Global Digital Elevation Map (n.d.) [online] https://asterweb.jpl.nasa.gov/gdem.asp (accessed 11 May 2020).

Bernstein, L. et al. (2007) IPCC - Intergovernmental Panel on Climate Change [online] http://www.ipcc.ch/publications_and_data/publications_climate_change_2007_the_ar4_synthe sis_report_french.htm (accessed 30 October 2018).

Blanco-Gómez, P., Jimeno-Sáez, P., Senent-Aparicio, J. and Pérez-Sánchez, J. (2019) 'Impact of climate change on water balance components and droughts in the Guajoyo River Basin (El Salvador)', Water, Vol. 11, p.2360 [online] https://doi.org/10.3390/w11112360.

Block, P.J., Filho, F.A.S., Sun, L. and Kwon, H-H. (2009) 'A streamflow forecasting framework using multiple climate and hydrological models', JAWRA J. Am. Water Resour. Assoc., Vol. 45, pp.828-843 [online] https://doi.org/10.1111/j.1752-1688.2009.00327.x.

Bouraoui, F., Benabdallah, S., Jrad, A. and Bidoglio, G. (2005) 'Application of the SWAT model on the Medjerda river basin (Tunisia)', Phys. Chem. Earth Parts ABC, Vol. 30, pp.497-507 [online] https://doi.org/10.1016/j.pce.2005.07.004.

Brouziyne, Y., Abouabdillah, A., Bouabid, R. and Benaabidate, L. (2017) 'SWAT streamflow modeling for hydrological components' understanding within an agro-sylvo-pastoral watershed in Morocco', J. Mater. Environ. Sci., Vol. 9, pp.128-138 [online] https://doi.org/ 10.26872/jmes.2018.9.1.16.

Brouziyne, Y., Abouabdillah, A., Hirich, A., Bouabid, R., Zaaboul, R. and Benaabidate, L. (2018) Modeling Sustainable Adaptation Strategies Toward a Climate-smart Agriculture in a Mediterranean Watershed Under Projected Climate Change Scenarios, Vol. 9, No. 1, pp.154-163 [online] https://doi.org/10.26872/jmes.2018.9.1.16.

Chen, J., Brissette, F.P. and Leconte, R. (2011) 'Uncertainty of downscaling method in quantifying the impact of climate change on hydrology', J. Hydrol., Vol. 401, pp.190-202 [online] https://doi.org/10.1016/j.jhydrol.2011.02.020.

Chen, J., Brissette, F.P., Chaumont, D. and Braun, M. (2013) 'Finding appropriate bias correction methods in downscaling precipitation for hydrologic impact studies over North America', Water Resour. Res., Vol. 49, pp.4187-4205 [online] https://doi.org/10.1002/wrcr.20331.

CORDEX (n.d.) Regional Climate Model Evaluation System [online] https://rcmes.jpl.nasa.gov/ content/cordex (accessed 19 December 2018).

CORDEX Data Search (n.d.) CORDEX | ESGF-CoG [online] https://esg-dn1.nsc.liu.se/search/ cordex/ (accessed 30 October 2018).

Dosio, A. and Panitz, H-J. (2016) 'Climate change projections for CORDEX-Africa with COSMO-CLM regional climate model and differences with the driving global climate models', Clim. Dyn., Vol. 46, pp.1599-1625 [online] https://doi.org/10.1007/s00382-0152664-4.

Ehret, U., Zehe, E., Wulfmeyer, V., Warrach-Sagi, K. and Liebert, J. (2012) 'HESS opinions "should we apply bias correction to global and regional climate model data?", Hydrol. Earth Syst. Sci., Vol. 16, pp.3391-3404 [online] https://doi.org/10.5194/hess-16-3391-2012.

ESGF-LIU (n.d.) Home | ESGF-CoG [online] https://esg-dn1.nsc.liu.se/projects/esgf-liu/ (accessed 16 December 2018). 
Estrela, T., Pérez-Martin, M.A. and Vargas, E. (2012) 'Impacts of climate change on water resources in Spain', Hydrol. Sci. J., Vol. 57, pp.1154-1167 [online] https://doi.org/10.1080/ 02626667.2012 .702213$.

Fang, G.H., Yang, J., Chen, Y.N. and Zammit, C. (2015) 'Comparing bias correction methods in downscaling meteorological variables for a hydrologic impact study in an arid area in China', Hydrol. Earth Syst. Sci., Vol. 19, pp.2547-2559 [online] https://doi.org/10.5194/hess-192547-2015.

FAO (n.d.) Harmonized World Soil Database.

Gan, T.Y., Ito, M., Huelsmann, S., Qin, X., Lu, X.X., Liong, S.Y. et al. (2016) 'Possible climate change/variability and human impacts, vulnerability of drought-prone regions, water resources and capacity building for Africa', Hydrol. Sci. J., Vol. 61, pp.1209-1226 [online] https://doi. org/10.1080/02626667.2015.1057143.

Grusson, Y., Anctil, F., Sauvage, S. and Perez, J.M.S. (2017) 'Testing the SWAT model with gridded weather data of different spatial resolutions', Water, Vol. 9, p.54 [online] https://doi. org/10.3390/w9010054.

Hagemann, S., Machenhauer, B., Jones, R., Christensen, O.B., Déqué, M., Jacob, D. et al. (2004) 'Evaluation of water and energy budgets in regional climate models applied over Europe', Clim. Dyn., Vol. 23, pp.547-567 [online] https://doi.org/10.1007/s00382-004-0444-7.

Hernández-Díaz, L., Laprise, R., Sushama, L., Martynov, A., Winger, K. and Dugas, B. (2013) 'Climate simulation over CORDEX Africa domain using the fifth-generation Canadian regional climate model (CRCM5)', Clim. Dyn., Vol. 40, pp.1415-1433 [online] https://doi. org/10.1007/s00382-012-1387-z.

IPCC Working Group I, Stocker, T.F., Qin, D. et al. (2013) 'The physical science basis', in Stocker, T.F., Qin, D., Plattner, G-K., Tignor, M., Allen, S.K., Boschung, J., Nauels, A., Xia, Y., Bex, V. and Midgley, P.M. (Eds.): Contribution of Working Group I to the Fifth Assessment Report of the Intergovernmental Panel on Climate Change, Cambridge University Press, Cambridge, UK; New York, NY, USA, 1535pp.

Jacob, D., Petersen, J., Eggert, B., Alias, A., Christensen, O.B., Bouwer, L.M. et al. (2014) 'EURO-CORDEX: new high-resolution climate change projections for European impact research', Reg. Environ. Change, Vol. 14, pp.563-578 [online] https://doi.org/10.1007/ s10113-013-0499-2.

Kim, S., Noh, H., Jung, J., Jun, H. and Kim, H.S. (2016) 'Assessment of the impacts of global climate change and regional water projects on streamflow characteristics in the Geum River Basin in Korea', Water, Vol. 8, p.91, MDPI. [online] https://doi.org/10.3390/w8030091.

Kjellström, E., Nikulin, G., Hansson, U., Strandberg, G. and Ullerstig, A. (2011) '21st century changes in the European climate: uncertainties derived from an ensemble of regional climate model simulations', Tellus Dyn. Meteorol. Oceanogr., Vol. 2011, No. 63, pp.24-40 [online] https://doi.org/10.1111/j.1600-0870.2010.00475.x.

Knippertz, P., Christoph, M. and Speth, P. (2003) 'Long-term precipitation variability in Morocco and the link to the large-scale circulation in recent and future climates', Meteorol. Atmospheric Phys., Vol. 83, pp.67-88 [online] https://doi.org/10.1007/s00703-002-0561-y.

Kotlarski, S., Keuler, K., Christensen, O.B., Colette, A., Déqué, M., Gobiet, A. et al. (2014) 'Regional climate modeling on European scales: a joint standard evaluation of the Euro-CORDEX RCM ensemble', Geosci. Model Dev., Vol. 7, pp.1297-1333 [online] https://doi.org/10.5194/gmd-7-1297-2014.

Leander, R. and Buishand, T.A. (2007) 'Resampling of regional climate model output for the simulation of extreme river flows', J. Hydrol., Vol. 332, pp.487-496 [online] https://doi.org/ 10.1016/j.jhydrol.2006.08.006.

Lenderink, G., Buishand, A. and van Deursen, W. (2007) 'Estimates of future discharges of the River Rhine using two scenario methodologies: direct versus delta approach', Hydrol. Earth Syst. Sci., Vol. 11, pp.1145-1159 [online] https://doi.org/10.5194/hess-11-1145-2007.

Luo, M., Liu, T., Meng, F., Duan, Y., Frank1, A., Bao, A. et al. (2018) 'Comparing bias correction methods used in downscaling precipitation and temperature from regional climate models: a 
case study from the Kaidu River Basin in Western China', Water, Vol. 10, p.1046 [online] https://doi.org/10.3390/w10081046.

M'Po, Y.N., Lawin, A.E., Oyerinde, G.T., Yao, B.K. and Afouda, A.A. (2017) 'Comparison of daily precipitation bias correction methods based on four regional climate model outputs in Ouémé Basin, Benin', Hydrology, Vol. 4, p.58 [online] https://doi.org/10.11648/j.hyd. 20160406.11.

Majone, B., Bovolo, C.I., Bellin, A., Blenkinsop, S. and Fowler, H.J. (2012) 'Modeling the impacts of future climate change on water resources for the Gállego river basin (Spain)', Water Resour. Res., Vol. 48 [online] https://doi.org/10.1029/2011WR010985.

Maraun, D., Wetterhall, F., Ireson, A.M., Chandler, R.E. et al. (2010) 'Precipitation downscaling under climate change: recent developments to bridge the gap between dynamical models and the end user', Rev. Geophys., Vol. 48 [online] https://doi.org/10.1029/2009RG000314.

Mascaro, G., White, D.D., Westerhoff, P. and Bliss, N. (2015) 'Performance of the CORDEX-Africa regional climate simulations in representing the hydrological cycle of the Niger River basin', J. Geophys. Res. Atmospheres, Vol. 120, pp.12425-12444 [online] https://doi.org/10.1002/2015JD023905.

Meddi, M. and Hubert, P. (2003) 'Impact de la modification du régime pluviométrique sur les ressources en eau du nord-ouest de l'Algérie', Hydrol. Mediterr. Semiarid Reg., Vol. 278, pp.229-335.

Meddi, M., Talia, A. and Martin, C. (2009) 'Évolution récente des conditions climatiques et des écoulements sur le bassin versant de la Macta (Nord-Ouest de l'Algérie)', Physio-Géo Géographie Phys. Environ., pp.61-84 [online] https://doi.org/10.4000/physio-geo.686.

Meddi, M.M., Assani, A.A. and Meddi, H. (2010) 'Temporal variability of annual rainfall in the Macta and Tafna catchments, Northwestern Algeria', Water Resour. Manag., Vol. 24, pp.3817-33 [online] https://doi.org/10.1007/s11269-010-9635-7.

Milano, M., Ruelland, D., Fernandez, S., Dezetter, A., Fabre, J., Servat, E. et al. (2013) 'Current state of Mediterranean water resources and future trends under climatic and anthropogenic changes', Hydrol. Sci. J., Vol. 58, pp.498-518 [online] https://doi.org/10.1080/02626667. 2013.774458.

Muerth, M.J., St-Denis, B.G., Ricard, S., Velázquez, J.A., Schmid, J., Minville, M. et al. (2013) 'On the need for bias correction in regional climate scenarios to assess climate change impacts on river runoff', Hydrol. Earth Syst. Sci., Vol. 17, pp.1189-1204 [online] https://doi.org/ 10.5194/hess-17-1189-2013.

Nash, J.E. and Sutcliffe, J.V. (1970) 'River flow forecasting through conceptual models part I a discussion of principles', J. Hydrol., Vol. 10, pp.282-290 [online] https://doi.org/10.1016/ 0022-1694(70)90255-6.

National Agency of Hydrologic Resources (ANRH) (2003a) Map of Potential Evapotranspiration in the North of Algeria.

National Agency of Hydrologic Resources (ANRH) (2003b) Map of Average Annual Runoff in the North of Algeria.

National Agency of Hydrologic Resources (ANRH) (2003c) Map of Annual Rainfall in the North of Algeria.

Nerantzaki, S.D., Giannakis, G.V., Efstathiou, D., Nikolaidis, N.P., Sibetheros, I.A., Karatzas, G.P. et al. (2015) 'Modeling suspended sediment transport and assessing the impacts of climate change in a karstic Mediterranean watershed', Sci. Total Environ., Vol. 538, pp.288-297 [online] https://doi.org/10.1016/j.scitotenv.2015.07.092.

Osei, M.A., Amekudzi, L.K., Wemegah, D.D., Preko, K., Gyawu, E.S. and Obiri-Danso, K. (2019) 'The impact of climate and land-use changes on the hydrological processes of Owabi catchment from SWAT analysis', J. Hydrol. Reg. Stud., Vol. 25, p.100620 [online] https://doi.org/10.1016/j.ejrh.2019.100620. 
Panthou, G., Vrac, M., Drobinski, P., Bastin, S. and Li, L. (2016) 'Impact of model resolution and Mediterranean sea coupling on hydrometeorological extremes in RCMs in the frame of HyMeX and MED-CORDEX', Clim. Dyn., Vol. 51, pp.915-932 [online] https://link.springer. com/article/10.1007/s00382-016-3374-2.

Philandras, C.M., Nastos, P.T., Kapsomenakis, J., Douvis, K.C., Tselioudis, G. and Zerefos, C.S. (2011) 'Long term precipitation trends and variability within the Mediterranean region', Nat. Hazards Earth Syst. Sci., Vol. 11, pp.3235-3250 [online] https://doi.org/10.5194/nhess11-3235-2011.

Rathjens, H., Bieger, K., Srinivasan, R., Chaubey, I. and Arnold, J.G. (2016) CMhyd User Manual. Doc. Prep. Simulated Clim. Change Data Hydrol. Impact Study, Texas [online] http://swat.tamu.edu/software/cmhyd/.

Rosenzweig, C., Casassa, G., Karoly, D.J., Imeson, A., Liu, C., Menze, A. et al. (2007) AR4 Climate Change 2007: Impacts, Adaptation, and Vulnerability, IPCC.

Ruti, P.M., Somot, S., Giorgi, F., Dubois, C., Flaounas, E., Obermann, A. et al. (2016) 'Med-CORDEX initiative for Mediterranean climate studies', Bull. Am. Meteorol. Soc., Vol. 97, pp.1187-1208 [online] https://doi.org/10.1175/BAMS-D-14-00176.1.

Schilling, J., Freier, K.P., Hertig, E. and Scheffran, J. (2012) 'Climate change, vulnerability and adaptation in North Africa with focus on Morocco', Agric. Ecosyst. Environ., Vol. 156, pp.12-26 [online] http://dx.doi.org/10.1016/j.agee.2012.04.021.

Schmidli, J., Frei, C. and Vidale, P.L. (2006) 'Downscaling from GCM precipitation: a benchmark for dynamical and statistical downscaling methods', R. Meteorol. Soc., Vol. 26, pp.679-689 [online] https://doi.org/10.1002/joc.1287.

Senent-Aparicio, J., Pérez-Sánchez, J., Carrillo-García, J. and Soto, J. (2017) 'Using SWAT and fuzzy TOPSIS to assess the impact of climate change in the headwaters of the Segura River Basin (SE Spain)', Water, Vol. 9, p.149 [online] https://doi.org/10.3390/w9020149.

Shin, J-Y., Lee, T., Park, T. and Kim, S. (2018) 'Bias correction of RCM outputs using mixture distributions under multiple extreme weather influences', Theor. Appl. Climatol. [online] https://doi.org/10.1007/s00704-018-2585-3.

Solomon, S. and Intergovernmental Panel on Climate Change (2007) Climate Change 2007: The Physical Science Basis: Contribution of Working Group I to the Fourth Assessment Report of the Intergovernmental Panel on Climate Change, Cambridge University Press, Cambridge, New York.

Srinivasan, R., Zhang, X. and Arnold, J. (2010) 'SWAT ungauged: hydrological budget and crop yield predictions in the Upper Mississippi River Basin', American Society of Agricultural and Biological Engineers, Vol. 53, No. 5, pp.1533-1546.

Szabó-Takács, B., Farda, A., Skalák, P. and Meitner, J. (2019) 'Influence of bias correction methods on simulated Köppen-Geiger climate zones in Europe', Climate, Vol. 7, p.18 [online] https://doi.org/10.3390/cli7020018.

Taibi, S., Meddi, M., Mahe, G. and Assani, A. (2017) 'Relationships between atmospheric circulation indices and rainfall in Northern Algeria and comparison of observed and RCM-generated rainfall', Theor. Appl. Climatol., Vol. 127, pp.241-257 [online] https://doi. org/10.1007/s00704-015-1626-4.

Terink, W., Hurkmans, R., Torfs, P.J.J.F. and Uijlenhoet, R. (2010) 'Evaluation of a bias correction method applied to downscaled precipitation and temperature reanalysis data for the Rhine basin', Hydrol. Earth Syst. Sci., Vol. 14, p.17 [online] https://doi.org/10.5194/hess-14-6872010.

Teutschbein, C. and Seibert, J. (2010) 'Regional climate models for hydrological impact studies at the catchment scale: a review of recent modeling strategies', Geogr. Compass, Vol. 4, pp.834-860 [online] https://doi.org/10.1111/j.1749-8198.2010.00357.x.

Teutschbein, C. and Seibert, J. (2012) 'Bias correction of regional climate model simulations for hydrological climate-change impact studies: review and evaluation of different methods', J. Hydrol., Vols. 456-457, pp.12-29 [online] https://doi.org/10.1016/j.jhydrol.2012.05.052. 
Teutschbein, C. and Seibert, J. (2013) 'Is bias correction of regional climate model (RCM) simulations possible for non-stationary conditions?', Hydrol. Earth Syst. Sci., Vol. 17, pp.5061-5077 [online] https://doi.org/10.5194/hess-17-5061-2013.

The European Space Agency (n.d.) Land-Use Map [online] http://due.esrin.esa.int/page globcover.php (accessed 17 May 2017).

Thomas, L., Simon, D., Gwen, B. and Christel, P. (2012) 'Bias correction of daily precipitation simulated by a regional climate model: a comparison of methods', Int. J. Climatol., Vol. 33, pp.1367-1381 [online] https://doi.org/10.1002/joc.3518.

Tramblay, Y., Ruelland, D., Somot, S., Bouaicha, R. and Servat, E. (2013) 'High-resolution Med-CORDEX regional climate model simulations for hydrological impact studies: a first evaluation of the ALADIN-climate model in Morocco', Hydrol. Earth Syst. Sci., Vol. 17, pp.3721-3739 [online] https://doi.org/10.5194/hess-17-3721-2013.

UNEP/MAP-Plan Bleu (2009) State of the Environment and Development in the Mediterranean, Athens.

Vautard, R., Gobiet, A., Jacob, D. et al. (2013) 'The simulation of European heat waves from an ensemble of regional climate models within the EURO-CORDEX project', Clim. Dyn., Vol. 41, pp.2555-2575 [online] https://link.springer.com/article/10.1007/s00382-013-1714-z.

Vithlani, N.S. and Rank, H.D. (2016) 'Climate change impact assessment for Aji Basin using statistical downscaling and bias correction of climate model outputs', Curr. World Environ., Vol. 11, pp.670-678 [online] http://dx.doi.org/10.12944/CWE.11.2.40.

Wilby, R.L., Hay, L.E., Gutowski Jr., W.J., Arritt, R.W., Takle, E.S., Pan, Z. et al. (2000) 'Hydrological responses to dynamically and statistically downscaled climate model output', Geophys. Res. Lett., Vol. 27, pp.1199-1202 [online] https://doi.org/10.1029/1999GL006078.

Xiang, Z., Montas, H.J., Shirmohammadi, A., Leisnham, P.T. and Brubaker, K. (2018) Impact of Climate Change on Critical Source Areas in a Chesapeake Bay Watershed', Vol. 1801831, ASABE, Detroit, Michigan [online] https://doi.org/10.13031/aim.201801831.

Yang, J., Reichert, P., Abbaspour, K.C., Xia, J. and Yang, H. (2008) 'Comparing uncertainty analysis techniques for a SWAT application to the Chaohe Basin in China', J. Hydrol., Vols. 1-2, pp.1-23 [online] https://doi.org/10.1016/j.jhydrol.2008.05.012.

Yebdri, D., Errih, M., Hamlet, A. and El-Bari, T.A. (2007) 'The water resources management study of the Wadi Tafna basin (Algeria) using the SWAT model', Afr. Water J., Vol. 1, No. 1, pp.33-47.

Zanis, P., Kapsomenakis, I., Philandras, C., Douvis, K., Nikolakis, D., Kanellopoulou, E. et al. (2009) 'Analysis of an ensemble of present day and future regional climate simulations for Greece', Int. J. Climatol., Vol. 29, pp.1614-1633 [online] https://doi.org/10.1002/joc.1809.

Zeroual, A., Assani, A.A., Meddi, M. and Alkama, R. (2018) 'Assessment of climate change in Algeria from 1951 to 2098 using the Köppen-Geiger climate classification scheme', Clim. Dyn. [online] https://doi.org/10.1007/s00382-018-4128-0.

Zettam, A., Taleb, A., Sauvage, S., Boithias, L., Belaidi, N. and Sánchez-Pérez, J.M. (2017) 'Modelling hydrology and sediment transport in a semi-arid and anthropized catchment using the SWAT model: the case of the Tafna River (Northwest Algeria)', Water, Vol. 9, p.216 [online] https://doi.org/10.3390/w9030216.

Zittis, G., Hadjinicolaou, P., Klangidou, M., Proestos, Y. and Lelieveld, J. (2019) 'A multi-model, multi-scenario, and multi-domain analysis of regional climate projections for the Mediterranean', Reg. Environ. Change, Vol. 19, pp.2621-2635 [online] https://doi.org/10. 1007/s10113-019-01565-w. 